\title{
Anatomy, technology, art, and culture: toward a realistic perspective of the brain
}

\author{
Daniel D. Cavalcanti, M.D., ${ }^{1}$ William Feindel, M.D., C.M., ${ }^{2}$ \\ James T. Goodrich, M.D., Ph.D. ${ }^{3}$ T. Forcht Dagi, M.D., M.P.H, ${ }^{4}$ \\ Charles J. Prestigiacomo, M.D., ${ }^{5}$ and Mark C. Preul, M.D. ${ }^{1}$
}

\begin{abstract}
${ }^{1}$ Division of Neurological Surgery, Barrow Neurological Institute, St. Joseph's Hospital and Medical Center, Phoenix, Arizona; ${ }^{2}$ Department of Neurology and Neurosurgery, Montreal Neurological Institute and Hospital, McGill University, Montreal, Quebec, Canada; ${ }^{3}$ Division of Pediatric Neurosurgery, Albert Einstein College of Medicine, Children's Hospital at Montefiore, New York, New York; ${ }^{4}$ Harvard University-Massachusetts Institute of Technology Division of Health Sciences and Technology, Cambridge, Massachusetts; ${ }^{5}$ Department of Neurological Surgery and Radiology, Neurological Institute of New Jersey, New Jersey Medical School, University of Medicine and Dentistry of New Jersey, Newark, New Jersey
\end{abstract}

In the 15th century, brain illustration began to change from a schematic system that involved scant objective rendering of the brain, to accurate depictions based on anatomical dissections that demanded significant artistic talent. Notable examples of this innovation are the drawings of Leonardo da Vinci (1498-1504), Andreas Vesalius' association with the bottega of Titian to produce the drawings of Vesalius' De humani corporis fabrica (1543), and Christopher Wren's illustrations for Thomas Willis' Cerebri Anatome (1664). These works appeared during the Renaissance and Age of Enlightenment, when advances in brain imaging, or really brain rendering, reflected not only the abilities and dedications of the artists, but also the influences of important cultural and scientific factors. Anatomy and human dissection became popular social phenomena as well as scholarly pursuits, linked with the world of the fine arts. The working philosophy of these artists involved active participation in both anatomical study and illustration, and the belief that their discoveries of the natural world could best be communicated by rendering them in objective form (that is, with realistic perspective). From their studies emerged the beginning of contemporary brain imaging. In this article, the authors examine how the brain began to be imaged in realism within a cultural and scientific milieu that witnessed the emergence of anatomical dissection, the geometry of linear perspective, and the closer confluence of art and science. (DOI: 10.3171/2009.7.FOCUS09127)

\section{KEY WORDS • brain illustration • anatomy • dissection • neurosurgical history $\quad$ linear perspective}

\begin{abstract}
With what words $O$ writer can you with a like perfection describe the whole arrangement of that of which the design is here?
\end{abstract}

LEONARDO DA VINCI (CIRCA 1487)

The impetus for the dramatic progress in the illustration of the brain that began during the end of the 15th and into the 16th centuries, and that was elaborated upon during the next 2 centuries, has not been well explained. It has been suggested that the change began when anatomists concentrated on dissections of the ventricles and explored the existence of the rete mirabile, thus departing from the medieval cell doctrine of the brain. ${ }^{8,36}$ Other interpretations cite general increase in the level of intellectual curiosity during the Renaissance, or advancements in printing allowing illustrations to be included alongside descriptive text. ${ }^{5}$ Still others have suggested that the reemergence of human dissection as a legitimate field of inquiry underpinned the change in representation. , $8,10,30,35,36^{2}$ We suggest, however, that beyond the association between artist and anatomy, such analysis must interpret the man- ner in which the brain was illustrated as a function of the broader, interrelated changes occurring in science, art, and culture between the 15th and 17th centuries when the artist became dissector and vice versa. During this period, the brain becomes the seminal organ with which artists and anatomical science become preoccupied because it has been at the center of the search for man's soul for centuries. As such, the importance of the brain is not as just another organ for illustration; it is the organ that undergoes the most radical change in philosophy and art for true 3D representation.

Intriguing recent work on the history of concepts of death and attitudes toward the human body cites the advent of a "culture of dissection," 3,36 which began in the 1400 s and lasted at least 2 centuries. This work has provided a cultural context in which to trace what were, in the beginning, often illicit activities of the great anatomists and artists of the period, linking their work to a wider cultural and scientific discourse that embraced Renaissance art. Most artists became involved with anat- 


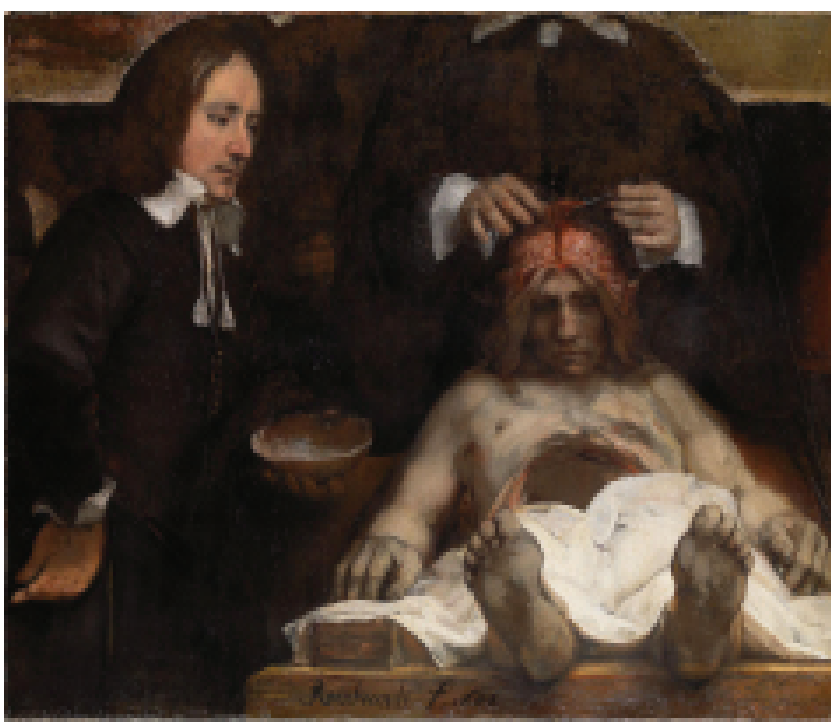

FIG. 1. The Anatomy Lesson of Dr. Deyman, oil on canvas, by Rembrandt van Rijn (1656). The dead man in the picture is Joris Fonteijn, known as "Black Jan," a thief who suffered the death penalty. As was usual in such dissections, the stomach and intestines were dissected before the brain. Gysbrecht Calcoen, a master of the Amsterdam guild of surgeons, assists and holds the calvaria while Deyman removes the falx. Note that Rembrandt chose to paint his signature on the dissection table, likely indicating his intimate familiarity with such scenes.

omy during the Renaissance and thereafter to help them portray the human body naturalistically, although there is meager information on how artists actually acquired anatomical familiarity (Fig. 1).9,30 The most important junctions of progress in brain illustration occurred with the real, intimate involvement of the anatomist as artist, or anatomist with artist.

Technical advances of this period had a far-reaching affect on art. Linear perspective, for example, introduced and mathematically modeled during the Renaissance, changed the way the human body was seen and shown. Perspective was not only an artist's or architect's tool, it also was a way of examining and recording the natural world. The philosophical influence of perspective appears to have made the most radical change to illustrating the brain, of all of the organs. In fact, before this change the brain was not really illustrated; what was shown were diagrams of the cell doctrine. Thus, depictions of strange, imaginary schematics gave way to revelations as the result of artistic, cultural, and scientific/technological influences.

Although we often believe that the past is a seamless web, in which changes point chiefly in a single direction, history also shows us that change may be varied, complex, multidirectional, and even contradictory. Accordingly, we suggest that any exploration of the fundamental changes that occurred in brain illustration must consider the cultural and scientific contexts of anatomical dissection, art, and optical science, which together dramatically affected how the natural world was understood and rendered. We address these interconnected notions in the following sections with artistic examples as they relate to the development and progression of realistic brain illustration.

\section{A Cultural Context for Anatomy}

Emergence of Dissection and Preservation of the Human Body

After a long period during which practical anatomy was ignored, dissection of the human body, a theologically sensitive issue, was revived during the late 13th century. The best known work of the period expounding upon first-hand observation of anatomy along with medical compilations from the Arabs, Anatomia, was written by Mondino de' Luzzi (ca. 1275-1326; Fig. 2). ${ }^{15}$ Initially, dissection was only allowed in medical schools; the general public knew little of such undertakings. In the 15th century attitudes toward dead bodies changed significantly. ${ }^{3}$ At that time it became popular to embalm bodies and entomb them rather than to dismember them for preservation in reliquaries. As a result of the renewed interest in embalming, interest and skill grew in anatomical dissection and techniques for tissue preservation. ${ }^{3,36}$

\section{Anatomy for Everyone}

Beginning in the 16th century, wealthy families often had a private dissection room in their homes, as later they might have had their own chemistry laboratory; the 2 rooms were often even combined. Anatomical demonstrations and dissections became publicly accessible. Hospitals had to have "anatomists sufficiently experienced to be able to prepare all the parts together and separately on different cadavers, and that all those who are obliged

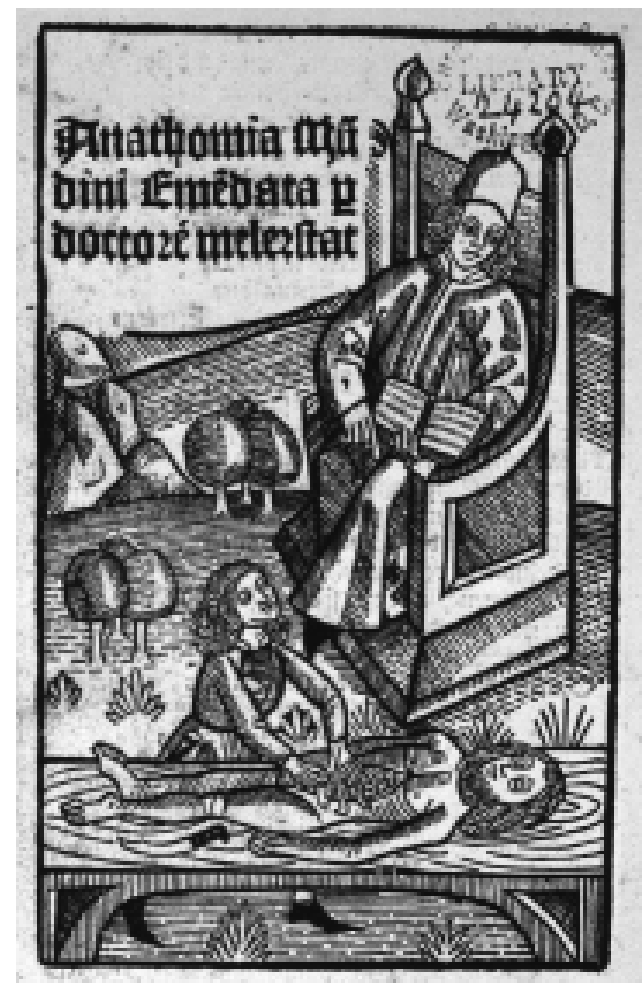

FIG. 2. Title page of Mondino de' Luzzi's Anatomia Mondini. The work was essentially a dissection manual and had great longevity; Mondino completed the book in 1316 and it was used for teaching anatomy for more than 200 years. It was published in approximately 30 manuscripts and editions between the 14th and 16th centuries.,15 


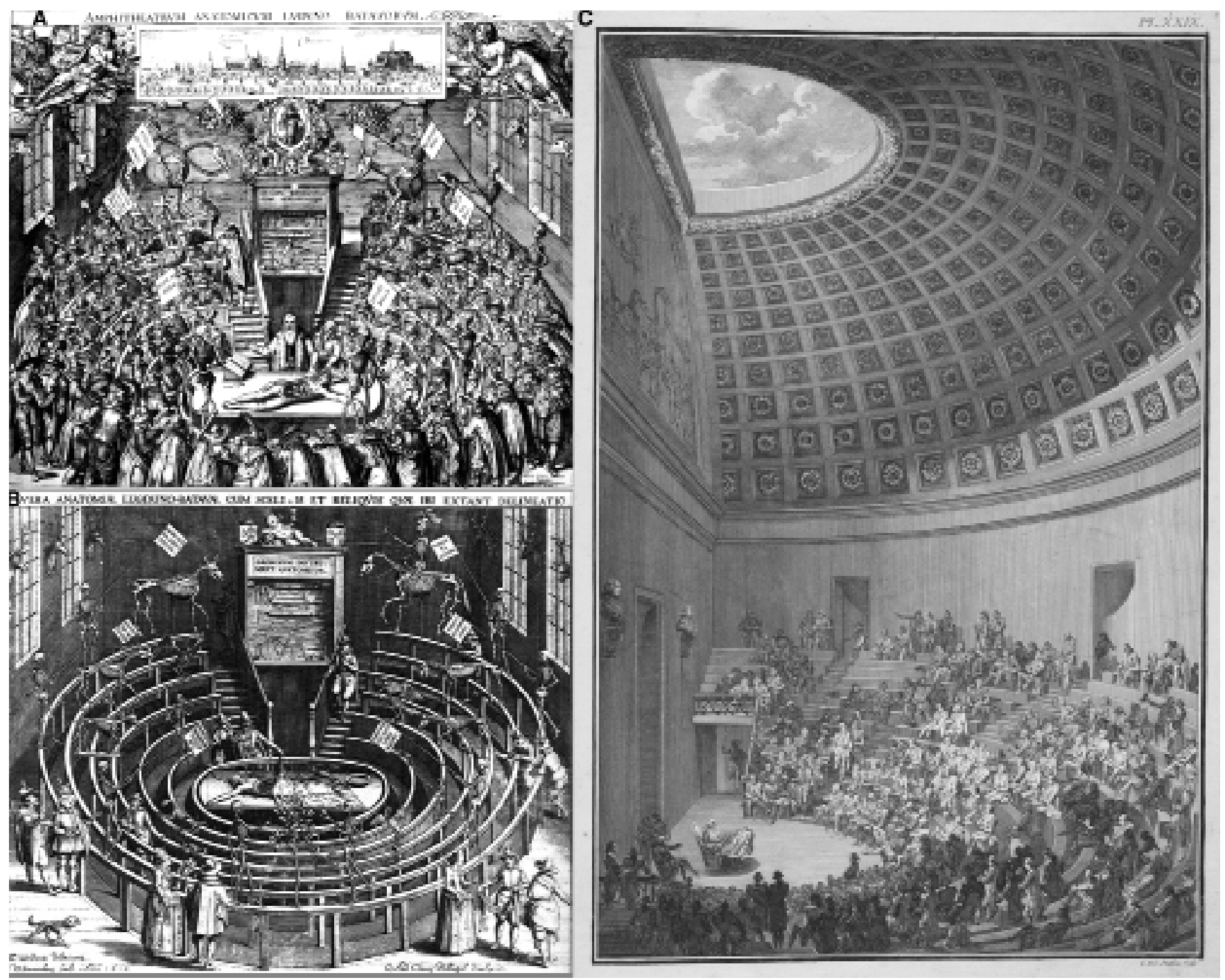

FIG. 3. Illustrations of different anatomy theaters. In the 16th century, the anatomy theater became both an index and advertisement of the intellectual state and culture of the community. The first anatomical theater was built at the University of Padua in 1594, while the Theatrum Anatomicum of Leiden University was opened in 1597 under the direction of Peter Pauw. The auditorium was equipped with 6 wide, flat, ascending rows of seats, so that the large windows remained uncovered and daylight could enter for illumination purposes. When the dissection was concluded, the auditorium was changed to an attractive museum. A: Anatomical lecture at the time of Peter Pauw, Dutch anatomist and physician (also called Pavius; 1564-1617). Engraving (1609) by Bartholomeus Dolendo, based on a drawing by Jan Cornelisz van 't Woud (Woudanus). B: Engraving of the anatomical theater in Leiden (1610) by Willem van Swanenburgh, based on a drawing by Jan Cornelisz van 't Woud (Woudanus). C: Anatomical theater at the School of Surgery in Paris (copperplate engraving from Claude-René-Gabriel Poulleau, reprinted from Gondoin: Description des Écoles de Chirurgie. Paris, 1780) designed by Jacques Gondoin and constructed between 1768 and 1775.

by professions or whom curiosity might move to educate themselves be permitted to go to these places." ${ }^{3}$ In fact, the word "anatomy" entered the vernacular during the 16th century, and was even used in poetry. Dictionaries defined someone who was cachectic or severely wasted from sickness as "a real anatomy."

Crowds, which were composed of physicians and medical students, the fashionable educated elite, members of the court and church, merchants, administrators, and princes, flocked to the anatomy theaters in Padua, Paris, Marburg, Leiden, Amsterdam, and London to see bodies dissected (Fig. 3). ${ }^{38}$ Anatomy lessons often provided a pretext for a group portrait with donors arranged around the subject of the dissection. ${ }^{37}$ Anatomy lessons or private dissections during this time were likened to a thesis defense or a college play, a great social event that could attract a whole town and often celebrated with masks, refreshments, and diversions. It was not unusual for men to invite women to private dissections as social occasions. ${ }^{3}$ Anatomical plates and drawings became fashionable gift and collectable items.

\section{Anatomy Is Fashionable}

Anatomy, however, was not only important for surgeons and physicians, it was also important to philoso- 


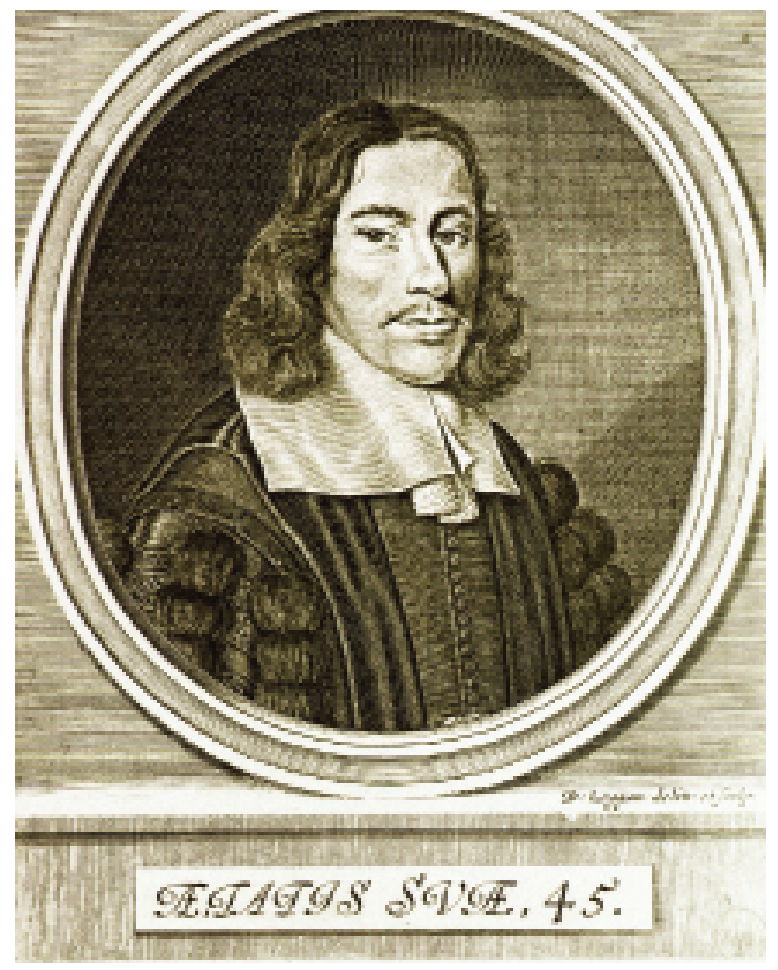

FIG. 4. Engraving of Thomas Willis by David Loggan (1667), from the title page of Pathologiae Cerebri. The force of Willis' arguments was strengthened by the excellence of the illustrations contained in his books. These illustrations provided a means of proposing an end to the concept of localization of brain function-sensus communis, imagination, and memory-in the ventricles by transferring these to the 3 regions in the brain: corpus striatum, corpus callosum, and cerebral cortex, respectively. Reprinted from T. Willis: Pathologiae Cerebri. London: Martyn, 1678.

phers, painters, sculptors, and even magistrates. Beginning in the 17th century, anatomy was part of the "indispensable equipment of every well-educated man."3 It began to be fashionable for people to become preoccupied with their bodies and even to go so far as to keep journals with daily accounts of bodily function and appearance.

In the 17th century, however, people also developed a fear of premature interment (being buried alive), ${ }^{3}$ an attitude that actually (and strangely) stimulated anatomical investigation. Many wills specifically indicated that the deceased should be dissected as a means to verify death. ${ }^{3}$ In keeping with instructions from a will, the family surgeon often performed the dissection discreetly in a private anatomy room. By the end of the 17th century the purpose and justification of dissection became less focused on preservation of the dead and more focused on efforts to obtain scientific knowledge and satisfy curiosity.

In the 18th century, knowledge of anatomy became important as a foundation for doctrines of natural theology. Diderot wrote that "knowledge of the self presupposes knowledge of the body, and knowledge of the body presupposes knowledge of a network of causes and effects so prodigious that there is not one that does not lead directly to the notion of an all-knowing and all-powerful intelligence." 33
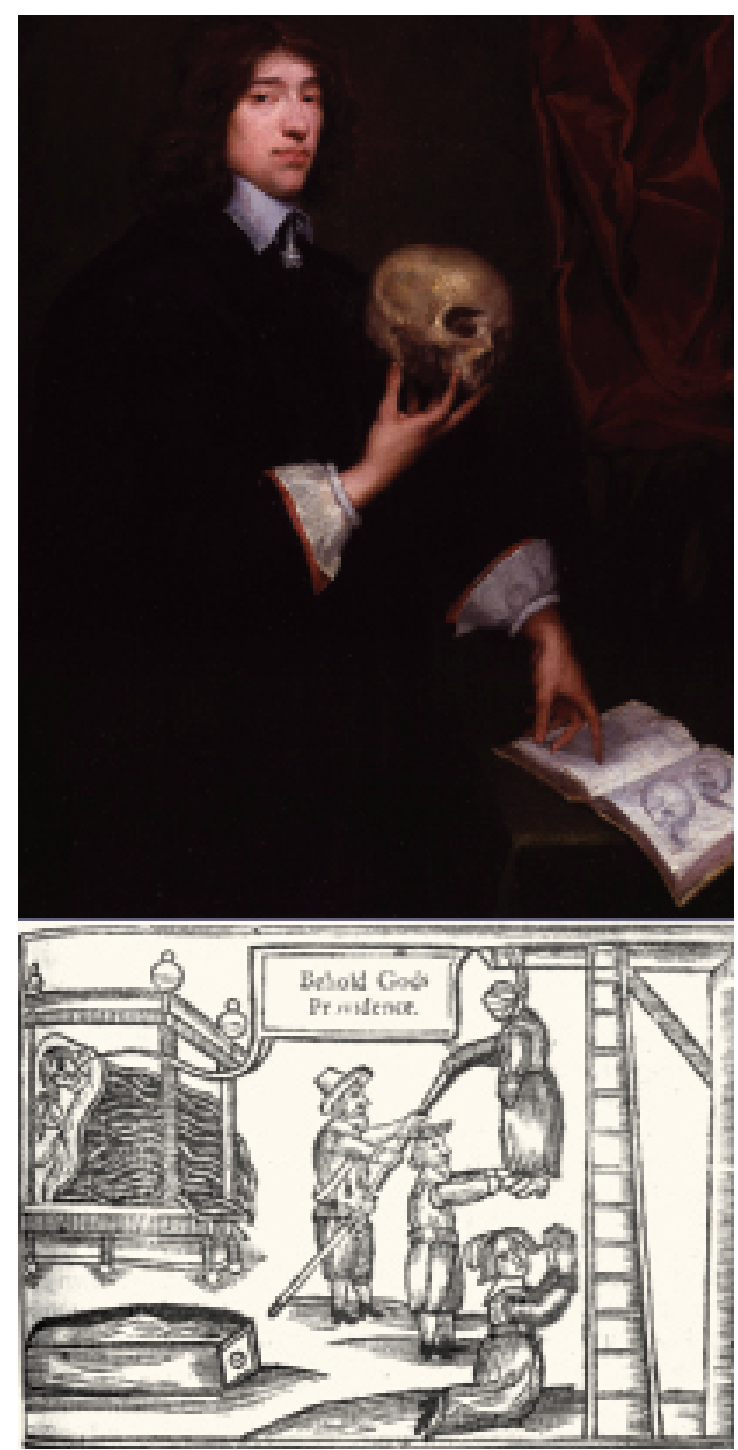

FIG. 5. Images of Sir William Petty. Upper: Painting of Petty, a political economist and philosopher, and pupil of Thomas Hobbes, who studied medicine at the University of Oxford (oil on canvas, by Isaac Fuller, 1649-1650). Petty was a longstanding medical colleague and mentor of Thomas Willis. They often performed private dissections together at Petty's residence in Oxford. Lower: Illustration of Petty assisting Willis in the "memorable accident and experiment" of the resuscitation of Anne Green, in 1651 (artist unknown). ${ }^{53}$

By the 18th century the competition from private dissections was so fierce that many town and education officials complained that young surgeons could not find enough bodies from which to gain anatomical experience. Cadavers were fought over or stolen from cemeteries, often by gangs composed of 4 young surgeons-the first to handle the guard dog, the second to descend into the grave with the ladder, the third to straddle the wall to throw the cadaver to the fourth, who carried the body to the carriage. The cadaver was then secreted away for dissection. Bodies were in constant demand because they decomposed quickly and were likely not used beyond a few days, especially in the hot summer months. Occa- 
The history of perspective in brain illustration
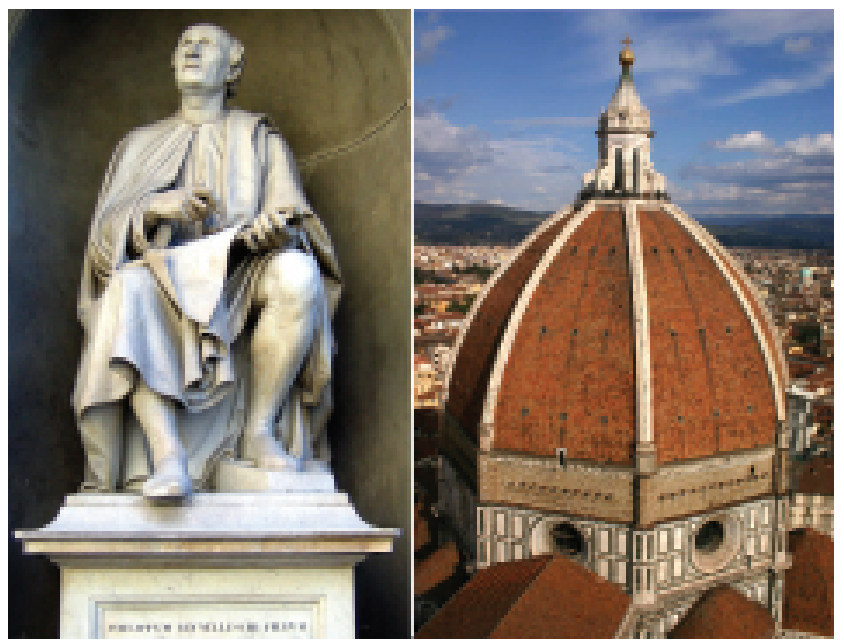

FIG. 6. Left: Statue of Filippo Brunelleschi by Luigi Pampaloni (1830) in the Pallazo dei Canonici in Piazza del Duomo, Florence, Italy. Right: Brunelleschi's masterpiece, the distinctive dome of the Cathedral of Santa Maria del Fiore in Florence, depicts an overlapping of the concepts of art, science, and technology.

sionally officials found bodies, sometimes even those of children, at the home or private facility of a doctor.

In his 1543 work De humani corporis fabrica (or simply Fabrica), Andreas Vesalius (1514-1564) enthusiastically describes exactly the best method to obtain sufficient anatomical material, at least for his brain examinations:

Heads of beheaded men are the most suitable since they can be obtained immediately after execution with the friendly help of judges and prefects. Among these is to be distinguished

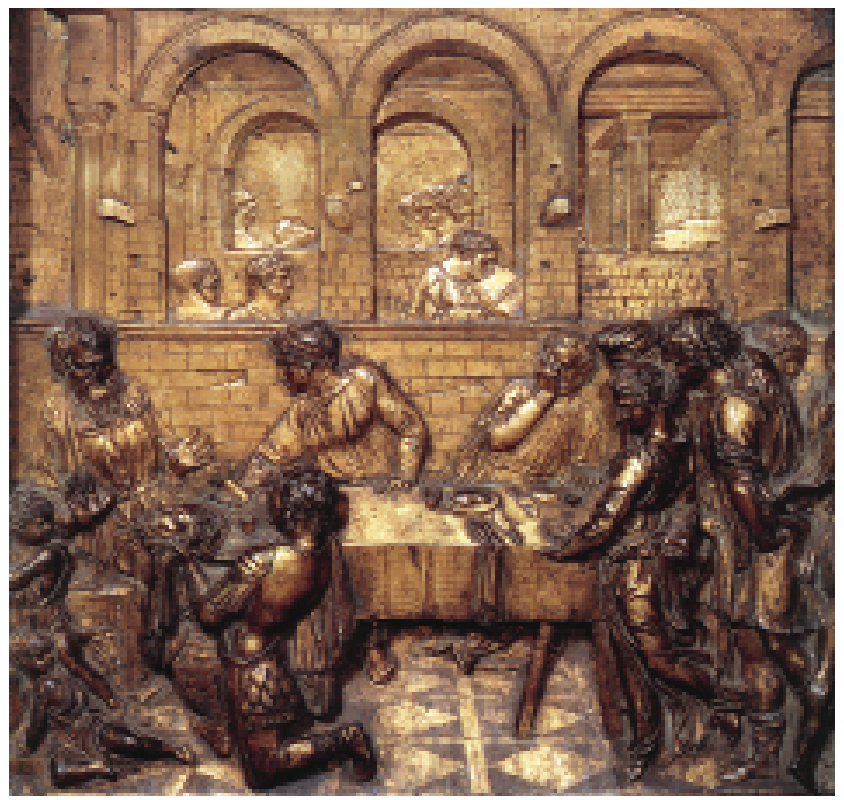

FIG. 7. Feast of Herod, a bronze sculpture by Donatello (1423-1427), located at the baptismal font of San Giovani, Siena, Italy, portraying the fateful birthday banquet hosted by Herod Antipas, son of Herod the Great, which resulted in the decapitation of Saint John the Baptist. This work was considered perhaps the earliest surviving example of a work of art using Brunelleschi's linear perspective.

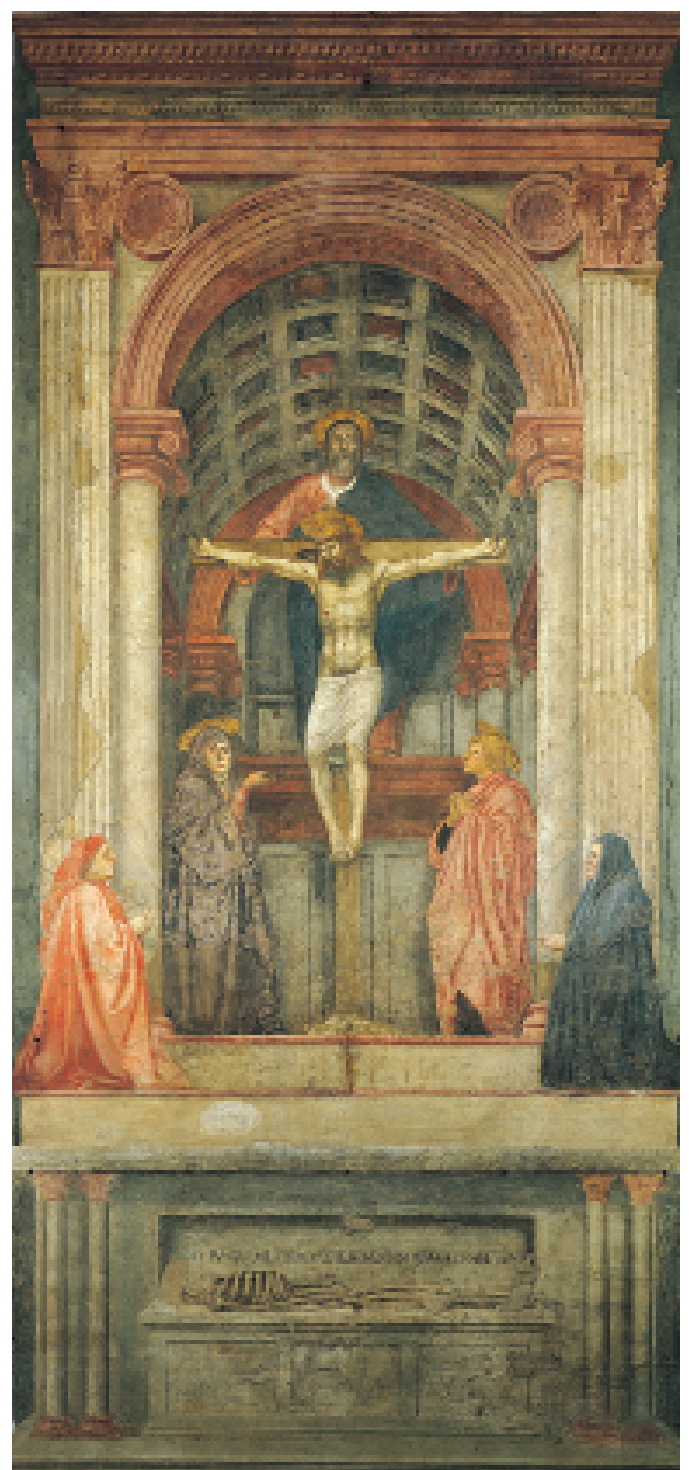

FIG. 8. Holy Trinity (full title: Trinity with the Virgin, Saint John the Evangelist, and Donors), a fresco by Masaccio (1425-1427), Church of Santa Maria Novella, Florence, Italy. The perspective lines of the barrel vault and its ceiling divided into squares simulate the continuation of the real world.

Marcantonio Contarini, that unique patron of learning, the pride of the illustrious Venetian senate.... He, so well known throughout the city and now a most zealous praetor of Padua, has supplied to us an abundance of material for dissections, for he is himself a studious and diligent observer of the fabrica of the human body, another Boethius or Sergius of the Romans. ${ }^{40}$

\section{The Mysteries of Anatomy}

The "fashionable success" of anatomy that began in the late 15th century and that entered its full development in the first half of the 17th century is not merely attributable to an increase in scientific or intellectual curiosity. It also reflects an attraction to ill-defined mysteries, fantasy, imagination, punishment, and ritual. During these periods, death and the grave were much more a part of daily life than they are today. Much of the world suffered 


\section{D. Cavalcanti et al.}

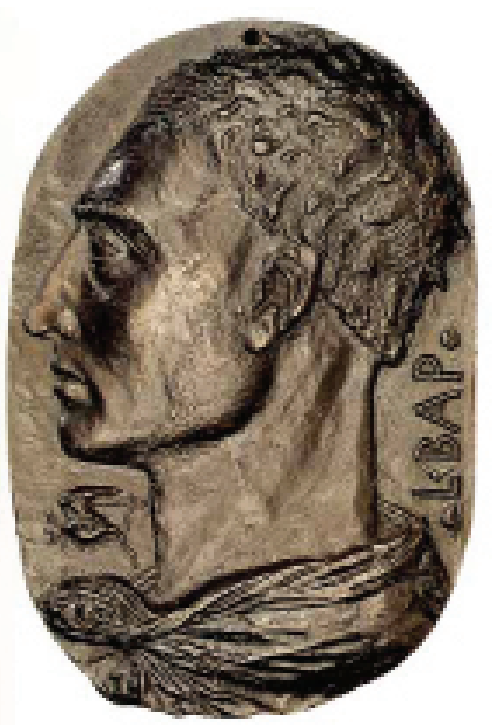

FIG. 9. Bronze plaque of a self-portrait of Leon Battista Alberti (1435). Leon Battista Alberti, Lorenzo Ghiberti, and Piero della Francesca were the 3 major contributors to the written theory of perspective before Leonardo da Vinci. Alberti wrote a short treatise, On Painting, in 2 versions: a Latin text, De Pictura, in 1435, and an Italian version, Della Pittura, dedicated to Brunelleschi, in 1436 that had direct consequences for the painting of the human form.

through the spread of various diseases that at times rapidly wiped out whole populations. Many would now interpret the prevailing interest in dissection and anatomy as morbid eroticism. This notion, however, reflects a moral attitude that developed in the 19th century and that would have been foreign to those living in the 15th, 16th, or 17th centuries.

Popular stories described people returning to life under the anatomist's scalpel. Thomas Willis (1622-1675), for example, was involved in the "memorable accident and experiment" of the resuscitation of Anne Greene after she was hanged for the murder of her bastard child in 1650 (Fig. 4). ${ }^{55}$ She was cut down and carried away to be "anatomiz'd by some young physicians." ${ }^{53}$ Finding her alive, Willis and his friend, William Petty (1623-1687), gave her "hot and cordiall spirits," among other remedies, and "put her to bed a warm woman" 53 (Fig. 5). Her recovery may have been influenced by an almost contemporary approach to resuscitation, in which the proverbial Oxford hypothermia may have played a beneficial role: her breathing in the coffin was first noticed by a fellow who "stamped on her breast and stomach severall times with all the force he could." 53 Willis and Petty took up a collection of money for her; she was pardoned, married, had several children, and lived 15 years after this lugubrious experience..$^{55}$

\section{Art Becomes Science}

\section{The Impact of Perspective}

Coincident with the cultural progression toward the study of anatomy, the invention of linear perspective in early 15 th century Florence, Italy, allowed artists to begin

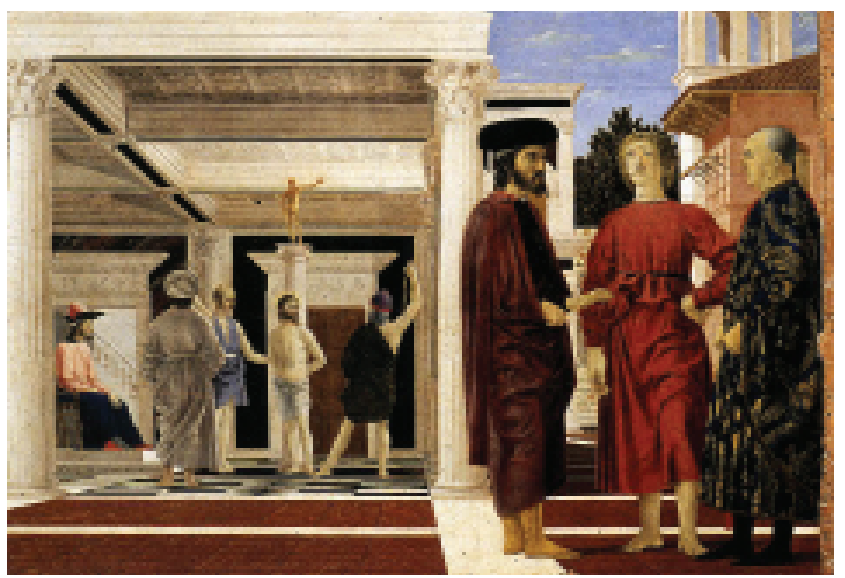

FIG. 10. The Flagellation of Christ, oil and tempera painting on panel by Piero della Francesca (1455), National Gallery of Marche, Urbino, Italy. In this painting, Piero defines the open gallery with impressive architectural perspective and distant groups of human figures. In $D e$ Prospectiva pingendi, Piero describes the rendition of solids in space (for example, the human head) by drawing different viewpoints with detailed reference numbers, which was an artistic precursor of the fiducials used in modern neurosurgical stereotaxis.

to create a systematic illusion of receding forms behind a flat surface. Geometrical procedures provided an appropriate means for the representation of 3D objects on a flat surface in such a way that the projection presented essentially the same visual arrangement to the eye as that presented by the original objects. It may be said that art became a science with the introduction and codification of linear perspective. Its arrival had radical consequences for the theory and practice of art and the nature of visual representation, including brain illustration.

\section{Filippo Brunelleschi Invents Linear Perspective}

Sometime before 1413, linear perspective was invented by Filippo Di Ser Brunellesco (1377-1446), better known as Filippo Brunelleschi, and remembered as the architect of the dome of Santa Maria del Fiore in Florence (Fig. 6), the Spedale degli Innocenti (Foundling Hospital), and the churches of San Lorenzo and Santo Spirito. ${ }^{26}$ Earlier artists such as Duccio (1255-1319), Giotto (1267-1337), and Pietro Lorenzetti (1280-1348) had developed stratagems for rendering space and solid objects, but they were not systematic or consistent and, most importantly, were not based on geometrical or optical proof.

Using a mirror and peephole (it has been proposed that a lens of some sort was also used), Brunelleschi proved the likenesses of 2 panels showing the Baptistery of San Giovanni on the Piazza del Duomo and the Piazza della Signoria of Florence in perspective to their real settings. This invention ultimately allowed artists to mix technical knowledge with theoretical sciences and provided an important impetus in the intellectual revolutions of the Renaissance. The skills that Brunelleschi introduced have been suggested to be central to the growth of practical mathematics in a mercantile society. ${ }^{26}$ The originality of Brunelleschi's work, based on geometrical and optical proof, was an outward expression of the advanced conceptual operation of Florentine society, in which the 


\section{The history of perspective in brain illustration}
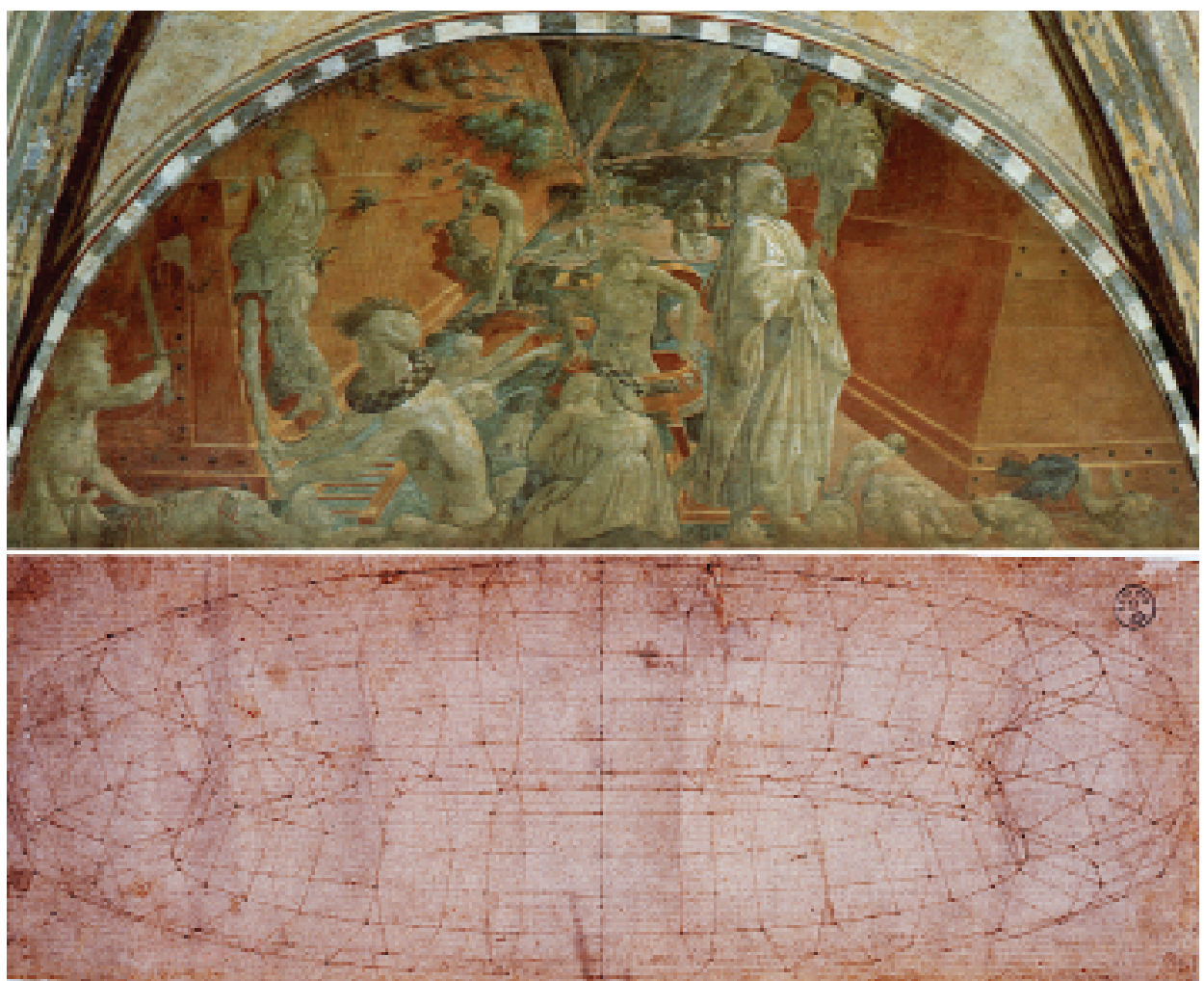

FIG. 11. Examples of the work by Paolo Uccello. The introduction of linear perspective in the artistic environment promoted an effusion of paintings and sculptures using the new technology. Uccello devoted most of his career to the study of perspective, conceiving complex structures as the mazzocchio in great detail. Uccello's wife told people that Paolo used to stay up all night in his study, trying to work out the vanishing points of his perspective, and that when she called him to come to bed he would say: "Oh what a lovely thing this perspective is!" Vasari believed that Uccello should have applied more time improving his paintings than in perspective constructions. ${ }^{11,44}$ Upper: Flood and Waters Subsiding, fresco by Paolo Uccello (1447-1448), Green Cloister, Church of Santa Maria Novella, Florence, Italy. L Lower: Mazzocchio, pen on white paper, by Paolo Uccello (1470), Uffizi Gallery, Florence.

more abstract principles of humanist learning conjoined fruitfully with the practical requirements of civic life.

The earliest surviving use of linear perspective in art is attributed to Donato di Niccolò di Betto Bardi (13861466), more commonly known as Donatello, in his bronze panel Feast of Herod (ca. 1425), made for the baptismal font of San Giovanni in Siena (Fig. 7). Masaccio's (born Tommaso Cassai 1401-ca. 1428) final masterpiece, Holy Trinity, painted for Santa Maria Novella in Florence around 1427, represents one of the oldest surviving perspective paintings (Fig. 8). Masaccio is considered by many to be one of the triumvirate, along with Brunelleschi and Donatello, who laid the foundations for the Renaissance in Italy.

\section{Codification of Linear Perspective}

Perspective, amenable to systematic description and to theoretical explanation, soon became codified in written form. The first of 3 major contributors to the written theory of perspective before Leonardo da Vinci was Leon Battista Alberti (1404-1472; Fig. 9), whose novel works ${ }^{26}$ instructed artists to "first sketch in the bones, for as they bend very little indeed, they always occupy a certain determined position. Then add the sinews and muscles, and finally clothe the bones and muscles with flesh and skin."
Although not a practicing painter, his approach to visual process was unequivocally mathematical-Alberti believed that a painting is the intersection of a visual pyramid at a given distance, with a fixed center and a defined position of light, represented by art with lines and colors on a given surface."',26

The science and theory of perspective were advanced by the great sculptor, Lorenzo Ghiberti (1378-1455), who carefully analyzed the experimental work of his contemporaries, absorbed new perspectival techniques, and added new styles. ${ }^{26}$ In his Commentaries, a compilation of texts from the medieval science of vision and an anthology of translations on the most advanced optical ideas then available, he wrote, “....in order always to understand first principles, I have striven to investigate in what manner nature functions in itself, and how I may be able to apprise nature, how the incorporeal images of objects come to the eye, and how the visual power operates, and how the visual sensations arise, and by what means the theory of the arts of sculpture and painting may be formulated." 52

\section{Extending the Mathematics of Perspective}

The work of the Florentine painter Piero della Francesca (ca. 1420-1492), De Prospectiva pingendi (On the 


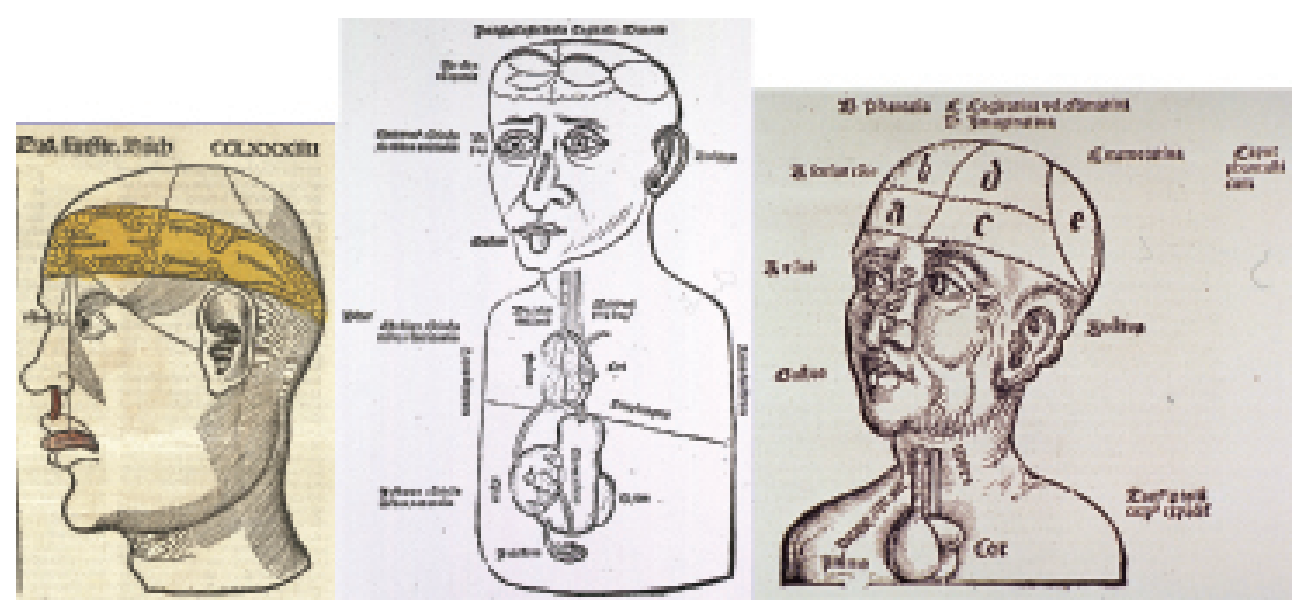

FIG. 12. Different representations of the medieval cell doctrine of brain function. These diagrams were often schematic and not intended to be necessarily realistic renderings of the brain. Because systematic human or animal dissection was not commonly practiced until at least the 13th century, few illustrations of the brain were drawn from or according to cadaveric specimens. Erroneous or incomplete anatomical knowledge was passed from copyist to copyist. This was especially true for illustrations made without the use of perspective techniques. Left: Hieronymus Brunschwig's illustration in Liber de arte distillandi de compositis (1512) is similar to the classic "Senses and their corresponding parts of the brain" by Gregor Reisch, published in Margarita Philosophica (1525). These diagrams were the most frequently reproduced during the medieval era. As shown, the senses of vision, olfaction, hearing, and gustation were projected in the first ventricle, which represented the common sense, the imagination, and fantasy. Passing through the vermis, the processed information had to be analyzed and comprehended at the second cell, the seat for cognition. The third cell held the process of memory. Reprinted from H. Brunschwig: Liber de Arte Distillandi de Compositis. Strasbourg: Johann Grüninger, 1512. Center: Illustration from Johannes Peyligk (1499) shows a concept of lateral and third and fourth ventricles, but the illustration for the brain bears little realism. Reprinted from J. Peyligk: Compendium Philosophiae Naturalis. Leipzig: Melchior Lotter, 1499. Right: An illustration from Mathias Qualle (1510) shows 5 areas for brain processes but appears to show no ventricles. Reprinted from M. Qualle: Habes Hic Amande Lector Textum Parvuli, Quod Aiunt, Philosophie Naturalis cum Commentariis. Hagenaw: Impensis Joannis Rynman, in officina Henrici Gran, 1513.

Perspective of Painting), ${ }^{16}$ written during the mid-1470s, may be regarded as a logical extension of the Albertian geometry of vision (Fig. 10). ${ }^{26,31}$ Piero investigated the nature of the proportional relationships left undefined by Euclid (330-275 BC); his work combined geometrical demonstrations with calculations of arithmetical ratios. Importantly, Piero established proportional laws that were concerned with the way in which the apparent size of an object at the intersection of proportional triangles or pyramids responds to its distances from the eye and the intersection.

\section{Perspective: An Impetus in the Shift Toward Objective Exploration of the Natural World}

For Alberti, Ghiberti, and especially Piero, pictures began to demand and demonstrate geometrical control, and paintings became scrupulously planned. In the 50 years after Masaccio's Holy Trinity, artists, especially in Italy, began to use perspectival designs in innovative ways. In the years after 1500 , perspective became an illustrative tool that touched all branches of applied science. Perspective "anticipated, stimulated, or even precipitated new visions of infinite or indefinite space and spurred intellectual and philosophical development."26

This new science literally took over men's lives. Paolo Uccello (1397-1475) became so delighted with this new technology that he devoted a great part of his time studying perspective, and both drawing and constructing complex structures for his painting (Fig. 11). Vasari wrote about Uccello's preoccupation with perspective:
When Paolo showed his intimate friend, Donatello the sculptor, mazzochi with projecting points and bosses, represented in perspective from different points of view, spheres with seventy-two facets like diamonds, and on each facet shavings twisted round sticks, with other oddities on which he wasted his time, the sculptor would say, 'Ah, Paolo, this perspective of yours leads you to abandon the certain for the uncertain; such things are only useful for marquetry, in which chips and oddments, both round and square, and other like things are necessary.' 44

The development of perspective was intimately involved in the shift from a medieval scholastic tradition to a tradition based on objective, individual exploration. It has been claimed that the development of perspective played a significant role in the industrialization of western civilization. Linear perspective changed the way man viewed his universe; although people obviously thought of objects in proportion, what was now crucial was that information could be communicated proportionally and in 3 dimensions. The world could now be described and rendered in mathematical terms. The impact was enormous, affecting art, architecture, engineering, weapons, machines, textiles, cartography, instruments, and the printing press. The discovery of perspective made industrialization possible: "Art, from a certain point on, provides the means of transmitting observations from which no amount of learned words could achieve in many fields."'l4

Explorations of the brain were included in this new approach. As art and science converged, the process of illustrating the brain was ready to enter a new era: "the modern concept of natural law over and against the medieval one."14 


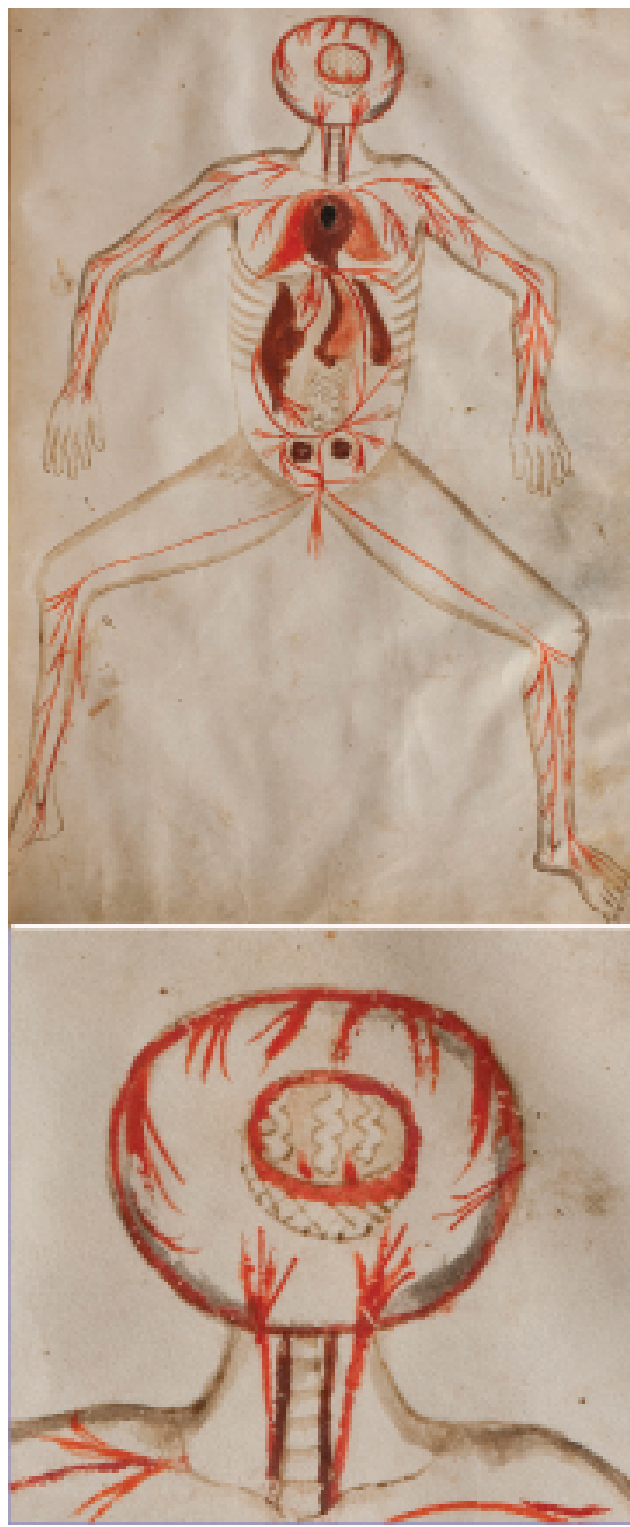

FIG. 13. The medical historian Karl Sudhoff described illustrations of the brain from medieval manuscripts. Upper: This drawing (artist unkown) illustrated a text originating in Salerno from around 1250. Although somewhat simplistically and stylistically rendered, this illustration represents an attempt at drawing the gyral-sulcal pattern of the cortex. Supporting this notion is the fact that the brain is rendered in a style consistent with the rest of the anatomical structures of the thoracic and abdominal cavities. Other aspects of the illustrations show vessels in the neck, vertebral segments, and extracranial vessels. The crosshatching may be a representation of the rete mirabile. Lower: Magnified view of the head and neck.

\section{Brain Illustration}

\section{Ancient and Medieval Periods}

No evidence in the tradition of Western medicine supports the use of illustrations in medical texts before the ancient Greeks. Aristotle (384-322 BC) referenced diagrams and sketches of physical and biological principles. The oldest illustrations available are from Alexandria and date to about 300 BC. Strangely, Galen (ca. 130-200) pro-
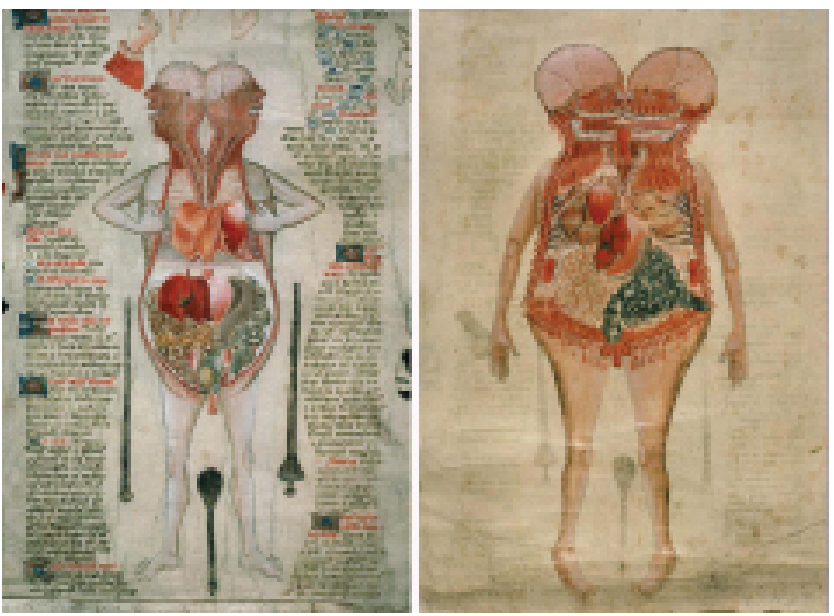

FIG. 14. Anatomical diagrams from De Arte Phisicali e de Cirurgia by John Arderne (1412), published after his death. Dr. Arderne had a great personal experience treating and writing about injuries of war from the Hundred Years' War of the 14th century, which saw the first battles to use gunpowder. These diagrams depict a cadaver split sagittally from head to perineum. Left: The brain is shown divided into frontal, middle, and posterior thirds and the gyri and sulci are represented with interrupted lines. The 3 sections might represent an attempt to illustrate portions of the brain found in the anterior, middle, and posterior fossae. Right: The artist maintained the same pattern of division of the skull, but another stroke rendering the brain. Some believe that because of the 3 sections, the drawing of the brain implies the 3-part cell or compartmentalization of the localization of mental functions, but there is nothing in the drawing implying this. The course of the inferior border of the brain gives a distinct impression that it follows the floor of the cranial vault. In addition, the brain is rendered consistent with an attempt to realistically portray other organs and body regions. The illustrations are not referred to in the text, which is largely concerned with ailments and remedies, thus implying little coordination between artist, author, or dissector.

moted direct visualization and observation as a means to inquire about biological form and relationships, but discouraged his students from relying on illustrations. No doubt he would have been disappointed to see the type of illustrations that were incorporated into his works as they endured the centuries.

Crude, and possessing little true representation of the anatomy underlying them, most medieval illustrations of the brain were conceptual diagrams or maps loosely based on anatomy and mainly used to illuminate concepts of the soul or explain the localization of mental functions and the senses (Fig. 12). Such drawings paralleled the status of paintings at the time:

...our attention is held, not so much by what we see, as what we do not see...The invisible element up to then in the paintings has been the living dispensation of God, his mysterious presence in all things: It was symbolized by the golden background which had no depth and yet suggested infinite depth. The image was strictly an intellectual symbol...The world of things was, as it should be, an emanation of the hypostasis of Soul, it had no depth of its own. ${ }^{14}$

However, there are illustrations of the brain from the 13th through the mid-14th centuries, some of which were based on dissection experience and are different from the conceptual diagrams that seem to have appeared at the end of this period. Illustrations from a text originating 


\section{D. Cavalcanti et al.}

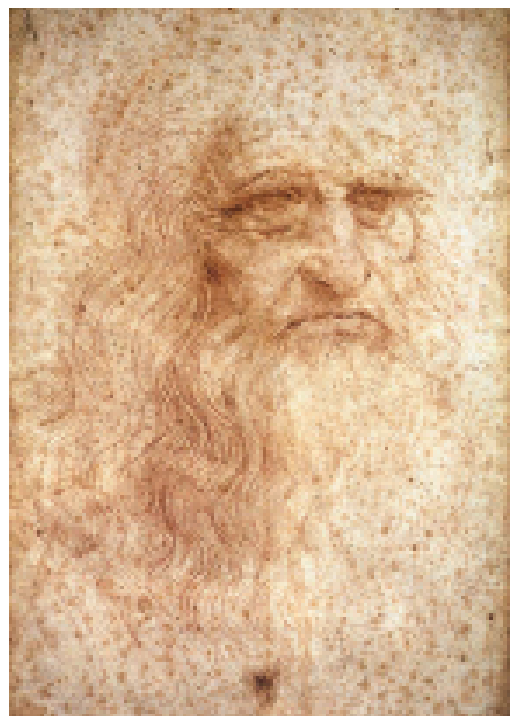

FIG. 15. A self-portrait of Leonardo da Vinci in red chalk (1510), from the Royal Library in Turin, Italy, within the time period that he was intensely performing anatomical dissection.

in Salerno from around the year 1250 refer to dissection of a man who was executed by drowning. ${ }^{43}$ One of the illustrations shows a circular structure within the cranial cavity that demonstrates a clear attempt to render brain gyri inside of it (Fig. 13). The artist, however, was ahead of his time and must not have been the author of the nonmatching text, as it describes 3 chambers in the brain, thus referring to the cell doctrine of ventricular mental function localization.

During the late Middle Ages, systematic illustrations of neuroanatomy are noted in Guido da Vigevano's 1345 work Anathomia Designata per Figures..$^{19}$ Da Vigevano was a student of Mondino in Bologna, and became physician to several courts in England and France. Importantly, his drawings imply an approach based on personal experience with cranial and vertebral dissections. ${ }^{19}$ Such illustrations were absent in Mondino's text-only Anatomia.

Unique illustrations are contained in a 1412 text on surgery and medicine written by John Arderne (13071392), a master surgeon of Newark. ${ }^{2}$ These illustrations show a man split sagittally from head to perineum (Fig. 14). Two of these illustrations show the brain and must have been based on a dissection because the brain is represented realistically compared with the other organs and structures. These early unusual illustrations are examples of attempts at true brain representation, and should be separated from those that are really conceptual images of the soul or the mental functions. These brain illustrations more accurately represent what is perhaps the earliest evidence of realistic brain imaging preceding the introduction of linear perspective.

\section{The Dawn of Modern Brain Imaging: The Search for True Representation}

Leonardo da Vinci. Leonardo da Vinci (1452-1519) was the first to combine the experience of an artist and dissector with a philosophy of perspective to render the brain with accuracy (Fig. 15). By the time that he had begun his training in the bottega of Andrea del Verrocchio (1435-1488), perspective had begun to be an established tool, at least in Florence, for any self-respecting artist. Leonardo was at the climax of the early development of perspective, and all of his studies were related to perspective in one way or another. Although his work on brain illustration did not have much influence on his
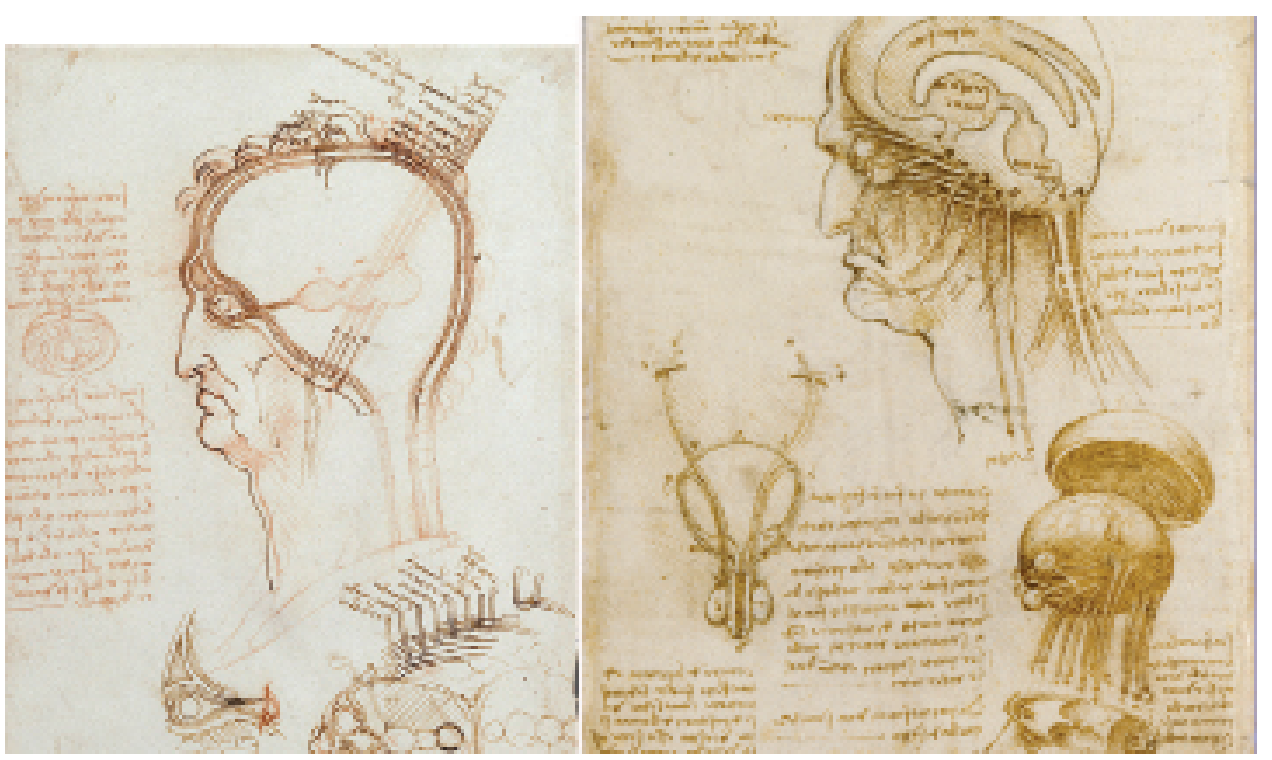

FIG. 16. Illustrations of the brain by Leonardo da Vinci. Left: "The Layers of the Scalp Compared with an Onion" in pen and ink (1490). Leonardo drew the brain according to the accepted notion of 3 cells, while the rest of the head, especially the face, was drawn realistically.13 Right: "Study of Brain Physiology," in pen and ink (1508). This rendering of the brain, ventricles, visual pathways, and skull base reveals Leonardo's dissection experience and break from traditional scholasticism, at least as far as personal experience and depiction are concerned. Sometime between 1504 and 1510, perhaps spurred by a renewed interest in anatomy and a kinship with Marcantonio, Leonardo became a "rapacious consumer" of cadavers.,31 


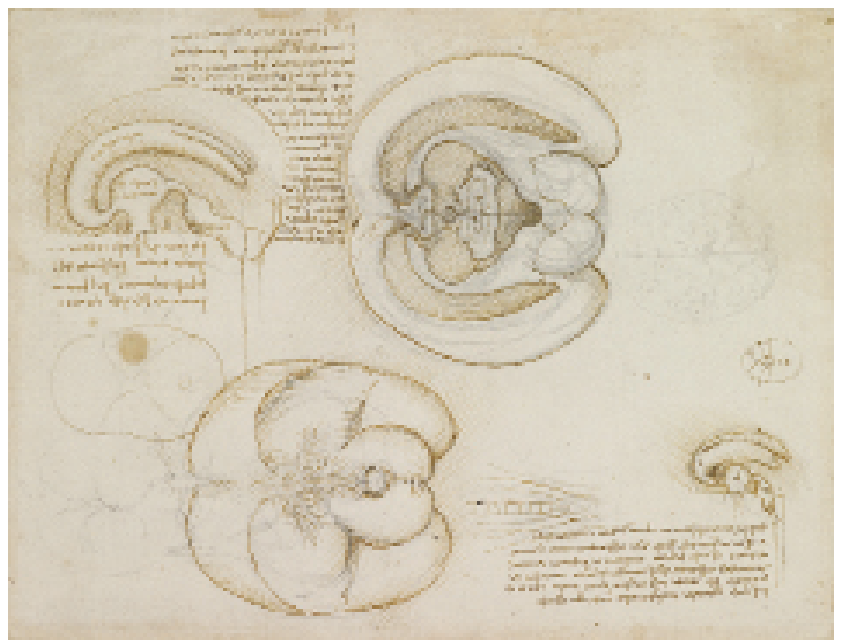

FIG. 17. Illustration of "The Brain Injected to Demonstrate the Shape of the Cerebral Ventricles," in pen and ink, by Leonardo da Vinci (15081510). By dissecting human cadavers and performing experiments with animals, Leonardo brought realism to his anatomical drawings. Note at the right side of this drawing one of the first attempts to reproduce a realistic rendering of the surface of the brain, with its sulcal-gyral pattern. This portion of the drawing is often cropped out of reproductions of this sketch page or is not well seen because it is faint, but it may be one of the most important drawings of the brain made by Leonardo. ${ }^{13}$

contemporaries, his work represents art and science in a rekindled relationship. Leonardo's varied but related experiences enabled him to develop an appreciation for perspective and proportion that allowed him to uniquely communicate his anatomical knowledge. Leonardo may have been the first artist to dissect brains himself and to conceptualize and illustrate the brain with skill, depth, and structural solidity (that is, with linear perspective).

In approximately 1487, Leonardo began to record his personal thoughts and experiences with anatomy. He recounted performing nocturnal dissections to become familiar with anatomy, and how to portray it:

This plan of mine of the human body will be unfolded to you just as though you had the natural man before you. The reason is that if you wish to know thoroughly the parts of a man after he has been dissected you must either turn him or your eye so that you are examining from different aspects, from below, from above and from the sides, turning him over and studying the origin of each limb; and in such a way the natural anatomy has satisfied your desire for knowledge.... And you who say that it is better to look at an anatomical demonstration than to see these drawings, you would be right, if it were possible to observe all the details shown in these drawings in a single figure, in which, with all your ability, you will not see nor acquire a knowledge of more than some few veins, while, in order to obtain an exact and complete knowledge of these, I have dissected more than ten human bodies, destroying all the various members, and removing even the very smallest articles of the flesh which surrounded these veins, without causing any effusion of blood other than the imperceptible bleeding of capillary veins. And as one single body did not suffice for so long a time, it was necessary to proceed by stages with so many bodies as would render my knowledge complete; and this I repeated twice over in order to discover differences.

But though possessed of an interest in the subject you may perhaps be deterred by natural repugnance, or, if this does not restrain you, then perhaps by the fear of passing the night hours

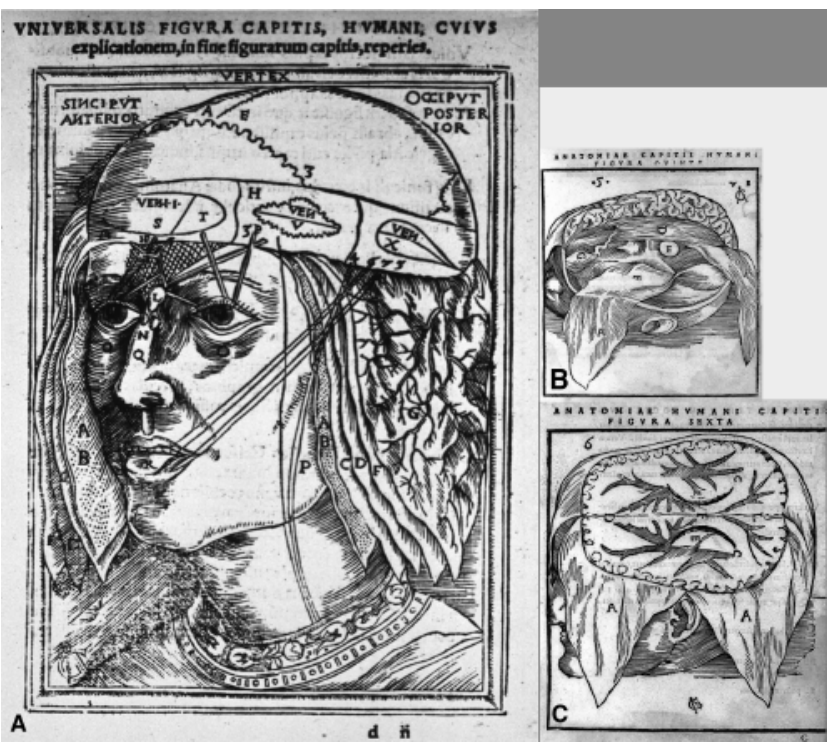

FIG. 18. Evidence of conflicting contemporaneous renderings by Johann Dryander during the transition from the medieval cell doctrine to the modern view of the brain. Published first in 1536, Anatomia Capitis Humani was expanded in the following year.20,25 This publication is regarded as the first text to illustrate a "Galenic dissection of the human brain"; that is, produced in accordance with actual dissections performed by the author and not through the assistance of a prosector. ${ }^{23,25}$ A: This drawing shows a complicated scheme for sense locations and for 3 cells that have subdivisions. It also demonstrates conflicting detail in anatomy and perspective: whereas in several cases the faces are quite well portrayed, layers of scalp and dura are present, and with consistent attention to cranial sutures, the illustration of the brain and ventricles remain rooted in the medieval scholastic cell tradition. The Galenic belief in the rete mirabile persisted in this illustration. ${ }^{20}$ B: Removal of the left cerebral hemisphere demonstrating the skull base, falx, and medial border of the right hemisphere. C: Axial section of the brain at the level of the body of the lateral ventricles revealing an early attempt to differentiate between the white and gray matters. Dryander possibly provided the most realistic renderings of the surface of the brain before Vesalius, such as this set of illustrations that depicted the interhemispheric fissure and falx, but he obviously did not have a similar command of involved talented artists as had Vesalius. Dryander, Berengario da Carpi, and Bartolomeo Eustachi, reflecting concepts from Leonardo, progressively provided more practical and realistic renderings of the brain, opening the doors to the Vesalian era. ${ }^{20}$

in the company of these corpses, quartered and flayed and horrible to behold; and if this does not deter you then perhaps you may lack the skill in drawing essential for such representation; and even if you possess this skill it may not be combined, you may not be versed in the methods of geometrical demonstration or the method of estimating the forces and strength of muscles, or perhaps you may be found wanting in patience so that you will not be diligent.

Concerning which things, whether or no they have all be found in me, the hundred and twenty books which I have composed will give their verdict 'yes' or 'no'. In these I have not been hindered either by avarice or negligence but only by want of time. Farewell. ${ }^{27}$

One can only imagine such a macabre scene, Leonardo spending hours upon hours at night in a dim candlelit room crouched over flayed bodies on tables, or sitting by wet dripping cadavers hanging by hooks. 
Leonardo's transition from traditional scholasticism to enlightenment is visible in his own corpus of work (Fig. 16). He embraced dissection and direct observation as a means to explore anatomy, but he continued to use the traditional labels of medieval brain physiology in his illustrations. ${ }^{9}$ However, we can identify the time when he broke cleanly from the past, at least graphically, exemplified in his renderings of the brain. In 1490, in a notebook that began with skull studies that he had started in 1489 , Leonardo inaccurately rendered drawings of the visual system and ventricles according to the accepted tradition of the cell doctrine (Fig. 16 left). The character of the subsequent sketches and drawings of the brain that he included in the book, however, was clearly and eminently changed.

Between 1504 and 1507, Leonardo's anatomical investigations became a sustained effort, and his methodology changed profoundly. Although Leonardo shed no light on his motivation for such a change, Vasari, Leonardo's pupil and heir, wrote, "Leonardo applied himself ... to the study of human anatomy, in which he collaborated with that excellent philosopher, Marcantonio della Torre ... one of the first to illustrate the problems of medicine by the teachings of Galen." ${ }^{45}$ Marcantonio (ca. 1481-1511) was a professor of anatomy at the University of Pavia, only 20 miles south of Leonardo in Milan. Sometime between 1504 and 1510, Leonardo performed the first wax injections of the ventricles within the brain of an ox (Fig. 17). Although he could not resist naming the ventricles with their traditional functional capabilities, his drawings based on these 3D investigations were realistic, revealing much of the true shape of the ventricles and surrounding structures. It has been suggested that Leonardo may have

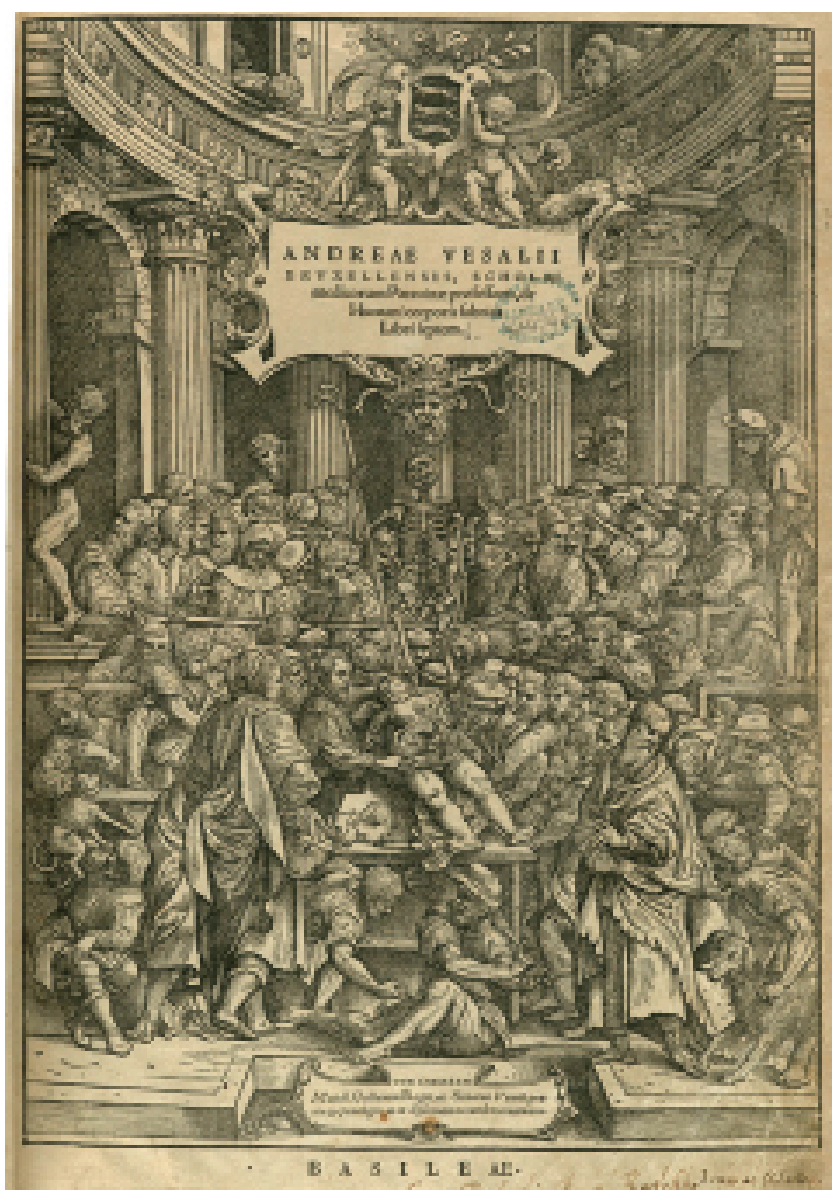

FIG. 19. The frontispiece to Andreas Vesalius's De humani corporis fabrica, first published in 1543.46
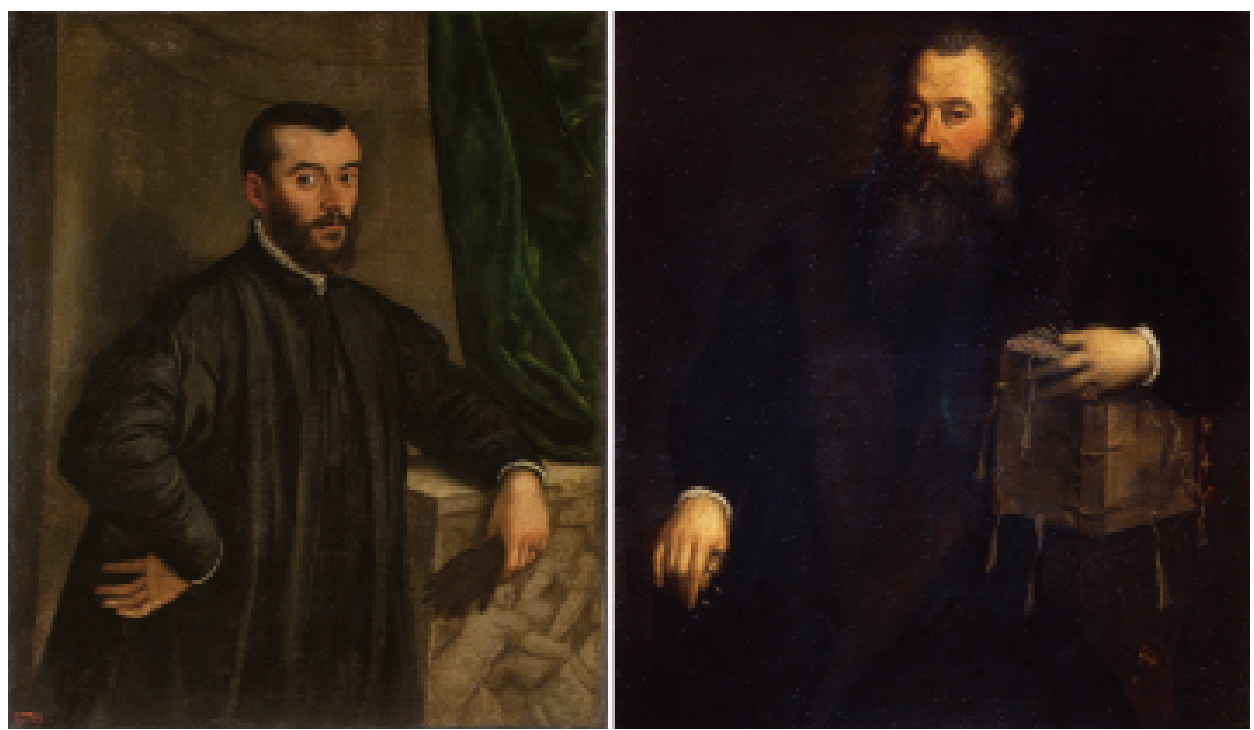

FIG. 20. Portraits of Andreas Vesalius that suggest his close association with Titian and Calcar. Left: Oil on canvas by Jan Stefan van Calcar (1546) that appears to show Vesalius with an appearance consistent with an age in the late twenties during which time he would have worked with Calcar. Vesalius made comments suggesting that a plurality of artists worked on the Fabrica and seems to have been somewhat sapped of energy by these associations: "[No longer] shall I have to put up with the bad temper of artists and sculptors [woodblock cutters] who made me more miserable than did the bodies I was dissecting!"29,48 One can only imagine the time and effort that went in to the Fabrica illustrations, and then to supervise their transfer to woodblocks, which is perhaps the reason why Vesalius did not again produce such a work. Right: Oil on canvas by Titian (1545). Note that Vesalius appears much older than 28 years of age. 


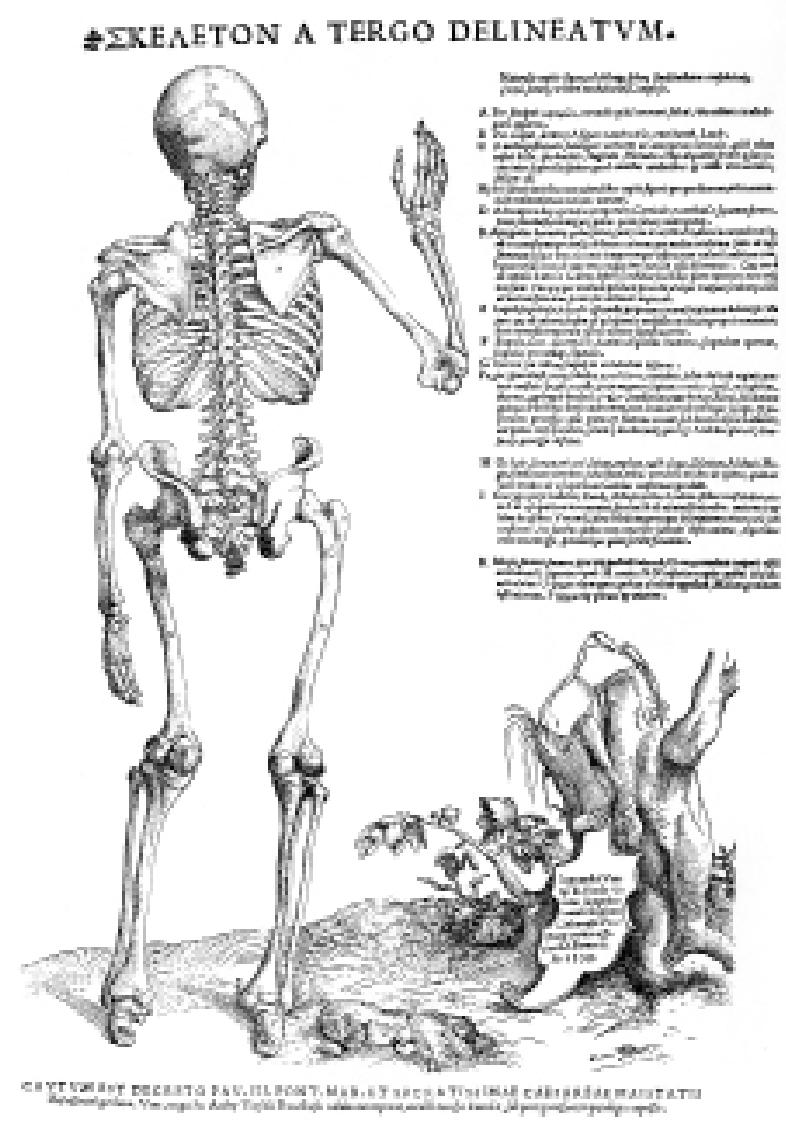

FIG. 21. The skeleton drawn from behind, appearing in the Tabula Sex (1538). On the scroll, propped against the tree stump, is written: "Printed at Venice by B. Vitalis of Venice, at the expense of Jan Stefan van Calcar. For sale in the shop of Signor Bernardus. In the year 1538." Along the bottom of the sheet are the privileges granted to Vesalius from the Pope, the Emperor, and the Venetian Senate, prohibiting others from reproducing this work. The Tabulae Sex was Vesalius' first anatomical publication, and consisted of only 6 plates, but set a new standard in anatomical illustration. The first 3 plates were based in the Galenic physiological principles and were signed by Vesalius. The other 3 plates depicting a skeleton in different aspects were made by Calcar. These last 3 plates are the only illustrations of Vesalius in which Calcar's authoring is wholly validated. ${ }^{35,47}$

accomplished this work in the medical school of the University of Pavia. ${ }^{9}$

Unfortunately for their association, Marcantonio died from plague in 1511, at about age 30. It appears that the end of this personal association interrupted Leonardo's directed efforts. His drawings and notes, intended for a projected study of the human figure according to plans that he devised in 1489, went unpublished until well after his death.

Subservience to authority frequently undermined Leonardo's theories and contributed little to understanding the nervous system. Nonetheless, graphically rendering the world around him in proper perspective became an inner philosophy. Leonardo's anatomical drawings began a revolution in communication: before the 16th century most scholars "strongly resisted the corruption of a text by images." $\mathrm{He}$ did not so much add science to art or art to science, as he showed how the science of art possessed a creative unity in relation to both form and content. To do so with regard to his anatomical investigations, Leonardo had to become both artist and anatomist. His sketches of the skull and brain were an outward manifestation of a system that was the first step toward accurate illustration of the brain.

Andreas Vesalius and the Atelier of Titian. Other brain anatomists, such as Berengario da Carpi (14601530), Johannes Eichmann (known as Dryander; 15001560), and Bartholomeo Eustachius (1520-1574), followed Leonardo. Together they provided an increasing realism in rendering the brain, ${ }^{23}$ under a clear influence of personal participation in anatomical dissections and improved fixation techniques. Although their drawings were not necessarily fully accurate, their work solidified the decline of the medieval view begun by Leonardo (Fig. 18). Moreover, their publications and illustrations laid the foundation for Vesalius to develop his famous works. There is evidence that Dryander and Vesalius may have been at least acquainted with each other's works. In Dryander's 1542 translation of Mondino's Anatomia, he plagiarized a portion of the text from Vesalius' 1538 Tabulae Sex, thereby angering the contemporary Vesalius. ${ }^{25}$

Although Andreas Vesalius is recognized as the greatest of the Renaissance anatomists, it is the illustrations from his book De humani corporis fabrica, first published in $1543,{ }^{46}$ by which he is best remembered (Figs. 19 and 20). The identity of the artist or artists used by Vesalius for his work remains controversial. Evidence points to Jan Stefan van Calcar (1499-1546), a student and nephew of Titian (1485-1576), as being at least meaningfully involved with the illustrations (Fig. 20). However, the evidence that might have been used to settle the dispute-
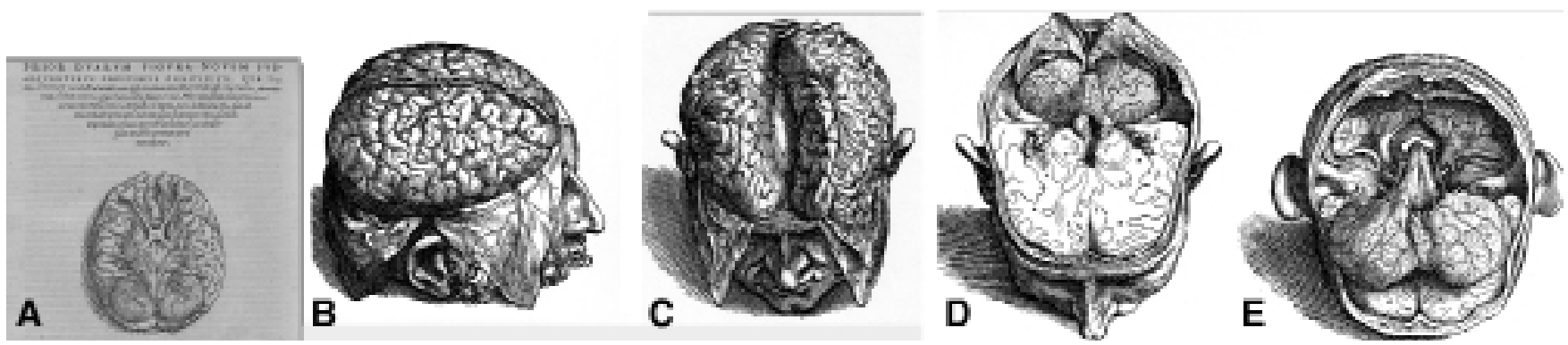

FIG. 22. Plates from the Fabrica. A: First figure of the fourth book showing the first realistic rendering of the base of the brain. B-E: Various figures of the seventh book of the Fabrica demonstrate that only excellent and novel means of preserving the brain would have allowed such dissection maneuvers and illustration. ${ }^{46}$ 


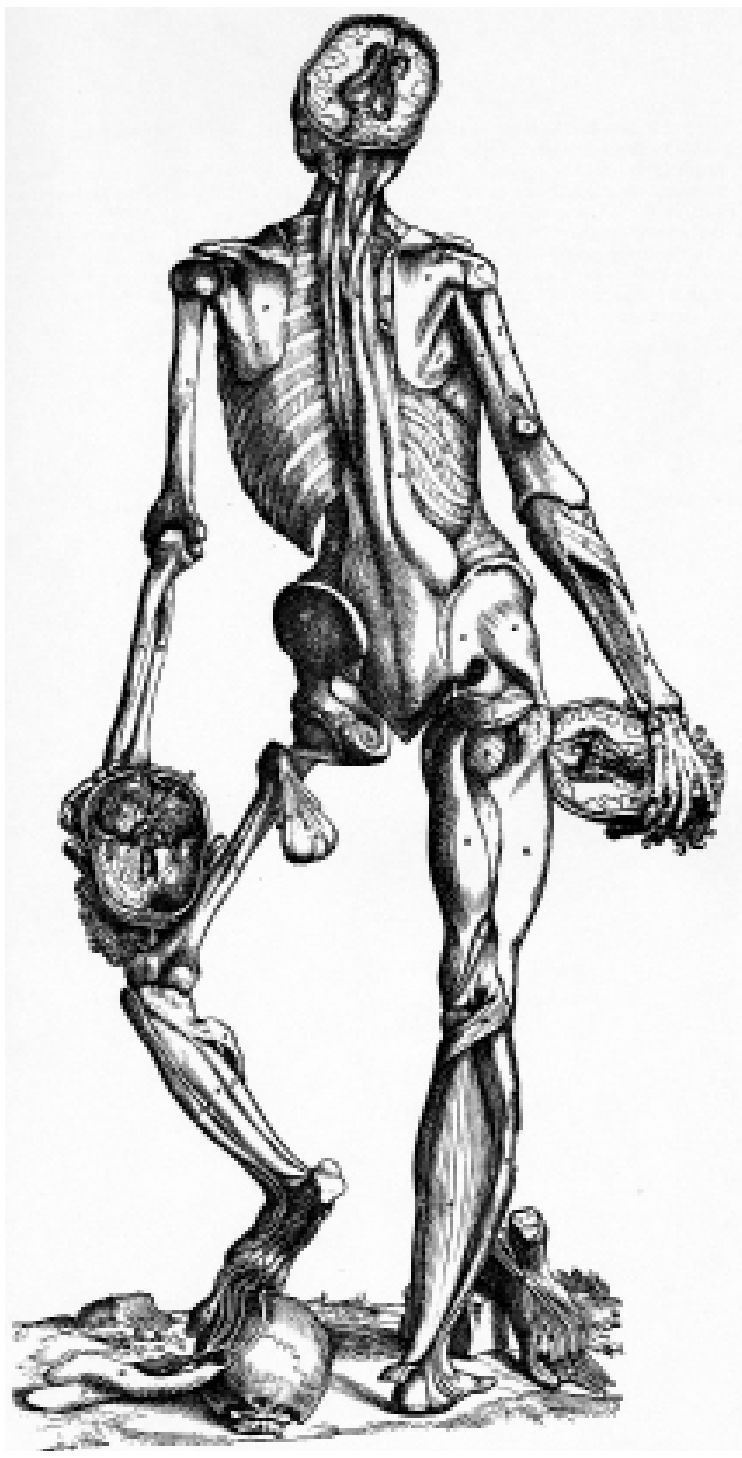

FIG. 23. Illustration from Vesalius' Epitome. The Epitome saw heavy use, and a complete copy of the Epitome is now more rare than the Fabrica as there are fewer than 20 surviving intact copies. Interestingly, very few copies of the Fabrica exist with any sort of annotations in the book, that is, with writings that would suggest that scholars actually read and used the book. ${ }^{49}$

wood blocks that were handed down, surviving a great deal of associated intrigue for 400 years - were destroyed during the World War II bombing of Munich, Germany. ${ }^{35}$ These wood blocks would have typically had the markings of the artist's or studio's initials. Although there are no direct references to the artist in the Fabrica, without question the artist was intimately involved with dissections conducted by Vesalius, whose comments reflect concern for the quality of the illustrations. The artist also may have been Titian, or assistants may have copied anatomical studies made by Titian in clearer outline and filled in anatomical detail under Vesalius' instruction. This scenario is supported by Vesalius' comments about the plurality of artists on the project. Regardless, even if Calcar only supervised the work, the implication remains of tremendous intimate involvement of the artists with the anatomist.
Calcar has become associated with the Fabrica because he, too, was Flemish and had not only produced some of the illustrations in Vesalius' prior work, Tabulae Sex, but also financed it. ${ }^{47}$ Furthermore, Calcar in Venice was only 20 miles away from Vesalius in Padua. Some of the drawings, however, were certainly the work of Vesalius himself. Vesalius' talent for illustration was referred to by a successor to the anatomy chair at Padua. Vesalius drew the first 3 plates of the Tabulae Sex (Fig. 21) and states that he drew all illustrations of the vessels in the Fabrica. ${ }^{12,35}$

Although it was an amazing work for Vesalius, then in his late twenties, much of the credit for the Fabrica must be given to the illustrators (Fig. 22). Although occasional illustrations had been used in anatomical texts before Calcar and Vesalius, such as those by Dryander and Eustachius, they were less successful, likely due to the quality of the art. Depictions of the brain were often distorted, especially its base, such as those by Veslingius and Casserius because of poor fixation techniques, , $^{, 50,55}$ Soon after its publication, many authors began to use freely (plagiarize) illustrations from the Fabrica, especially those of the brain and nervous system, which were the best that had yet been printed. ${ }^{12}$ The engravings needed no translation; they are still admired, copied, and used, even after almost 500 years (Figs. 22 and 23). ${ }^{46}$

The text of the Fabrica has been characterized as being composed in a rush ${ }^{12}$ and has even earned the characterization of sycophantic logomachy:

...verbose, repetitious, a very torrent of words; its idiom is awkward and conspicuously unsuited to it subject; its format is extremely inconvenient for the student's desk; its arrangement does not facilitate reference; it is inadequately indexed; its order is perplexing for the modern reader; it employs hundreds of technical terms, many new to the scientific Latin of their own day and many more that have passed out of use in our own; it is written from a philosophical point of view that is quite out of fashion; no translation of any substantial part of it was, till of late, readily accessible. ${ }^{40}$

Because it is hard to follow, much of the text remains unknown except to those with an intense interest in Vesalius, who subsequently described it himself as a "youthful labor of love written in commonplace and amateurish style." 12 In fact, many of the anatomical terms had to be made up as he went along. ${ }^{24}$

Although it was never widely read and the text has been "largely inaccessible," the Fabrica is one of the crowning achievements of the human spirit. ${ }^{40}$ Vesalius understood the importance of the illustrations in his ponderous tome and that the book was cumbersome to handle and too expensive for students. Concomitantly in 1543 he thus issued Epitome, ${ }^{49}$ essentially an abridged Fabrica that was printed along with suitable illustrations on 14 folio sheets. The Epitome became not only extremely popular as a handbook by virtue of its brevity and Vesalius's intention that it be "a foot-path beside the larger book to lead the student more gradually into the mainstream of the complexities of the human body," but also because of its illustrations (Fig. 23). Because of the conciseness of text, the illustrations in the Epitome might be considered to hold more prominence than in the Fabrica. Further substantiation to the importance of the illustrations was 


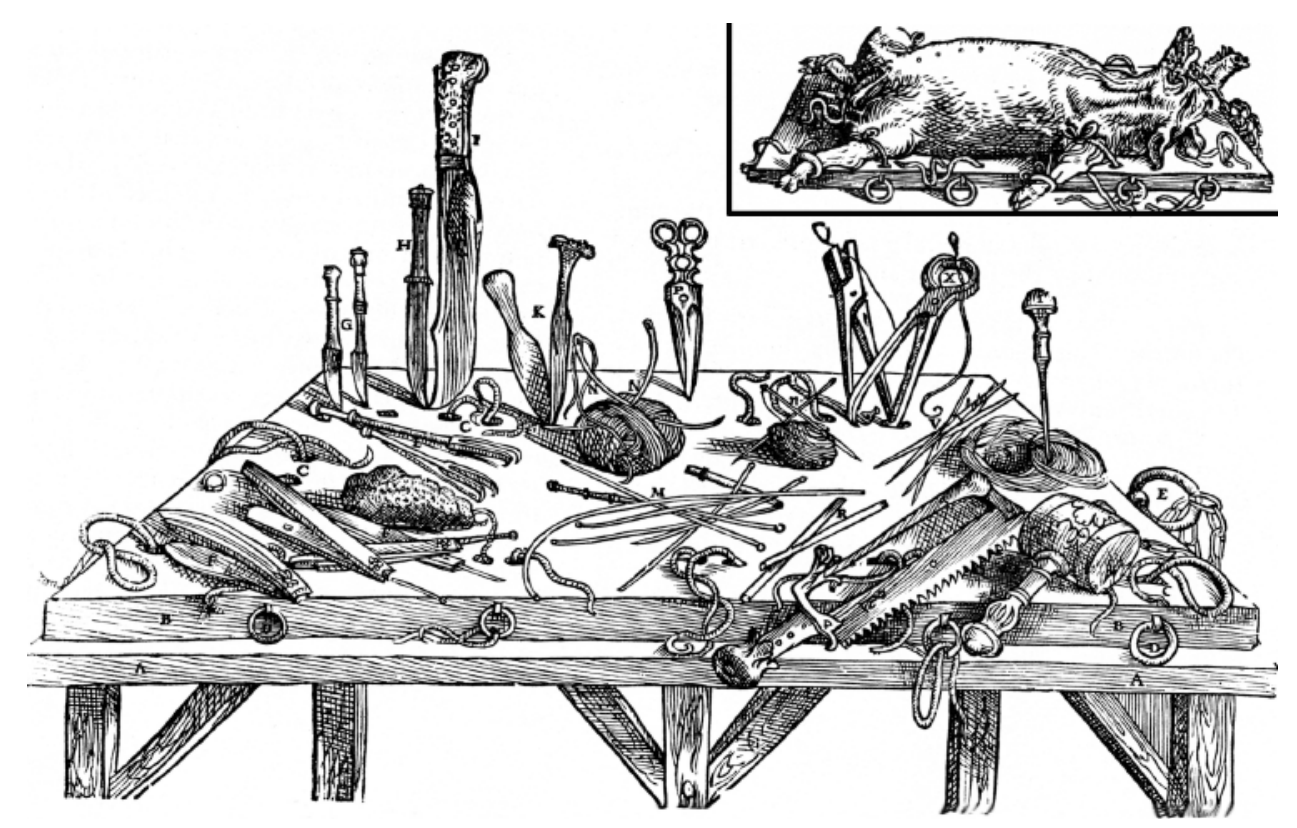

FIG. 24. Illustrations from the second book of the Fabrica. Table with instruments used by Vesalius in anatomical dissections and lessons, and experimental pig restrained on a wood board (inset). More than an anatomical publication, in the seventh book of Fabrica, Vesalius repeated physiological studies previously performed by Galen.

the unpopularity of the unillustrated, small, 2-volume pocket edition of the Fabrica with revised text that was printed in Lyon in $1552 . .^{12}$ There were no subsequent editions; without the illustrations from Titian's school with intimate supervision, it was not the same book.

The singular importance of the Fabrica was that for the first time, science (anatomical examination method and technology) and art were brought together to produce a cohesive, illustrated anatomical publication, especially for images of the brain. Vesalius recognized the singular importance of the brain and expressed wonderment at its function, but appears to have been frustrated that he could not explain it better: "I can in some degree follow the brain's functions in dissections of living animals, with sufficient probability and truth, but I am unable to understand how the brain can perform its office of imagining, meditating, thinking, and remembering, or, following various doctrines, however, you may wish to divide or enumerate the powers of the Reigning Soul." ${ }^{\text {40 }}$ Vesalius devotes Book VII of the Fabrica to his dissections of the brain, and in the introduction castigates the educational tradition of the "Philosophical Pearl" under which he also learned: "Such are the inventions of those who never look into our Maker's ingenuity in the building of the human body! How such people err in describing the brain will be demonstrated in our subsequent discussion." Vesalius demanded that anatomical and medical education must be gained by dissection and experiment. This emphasis is especially obvious by the last chapter of Fabrica, Book VII, that is devoted to a description of where to obtain anatomical material, the preparation of the tissues, and a complete method of dissection of the head (Fig. 24).

It has been suggested that the Fabrica was everything that Leonardo's collaboration with Marcantonio could have been, had the plague not struck Pavia in $1511 .{ }^{9}$
It showed that anatomist and artist must and could work together, and that the artist must possess intimate knowledge of dissection and the ability to render anatomy realistically. Such work must begin with bodies that may be diseased, from criminals hanged or drowned, or from buried bodies spirited away to the dissection room, with the process ending in the artist's studio. It was work that occurred centuries before the use of rubber gloves, requiring anatomist and artist to have their fingers in dank, cold, lifeless, decaying, stinking flesh and fluids. The Fabrica was revolutionary because of Vesalius' demand for accuracy and realism in anatomical illustration..$^{24} \mathrm{An}$ accomplished artist himself, Vesalius required the closest association between art and objectivity to ensure representational correctness of his work. The illustrations of the Fabrica, including those of the brain, are fluid visions of form in motion from multiple perspectives. But as well in Vesalius, we note a paradox, that without the convergence of people of various, specialized talents and without the intimate connection of science and art, the excitement and production of a communication like the Fabrica is not possible. ${ }^{24}$ After the Fabrica, it appears that Vesalius, for whatever reason, did not produce such a comparative work; was he lost without Calcar, who is said to have died 3 years after the publication of the Fabrica? ${ }^{29}$

Thomas Willis and Christopher Wren. There were works after Vesalius that are notable for their neurological images, although most contain works by draftsmen and artists that rendered the brain crudely, inaccurately, and in stylized ways, for example, as noted in the works of Arcangelo Piccolomini (1526-1605), Giulio Casserio (1561-1616), Caspar Bartholin (1585-1629), and Johann Vesling (1598-1649). Charles Estienne, trained by Sylvius and having worked in Padua, began a project with surgeon, anatomist, and artist Étienne de la Rivière (died 


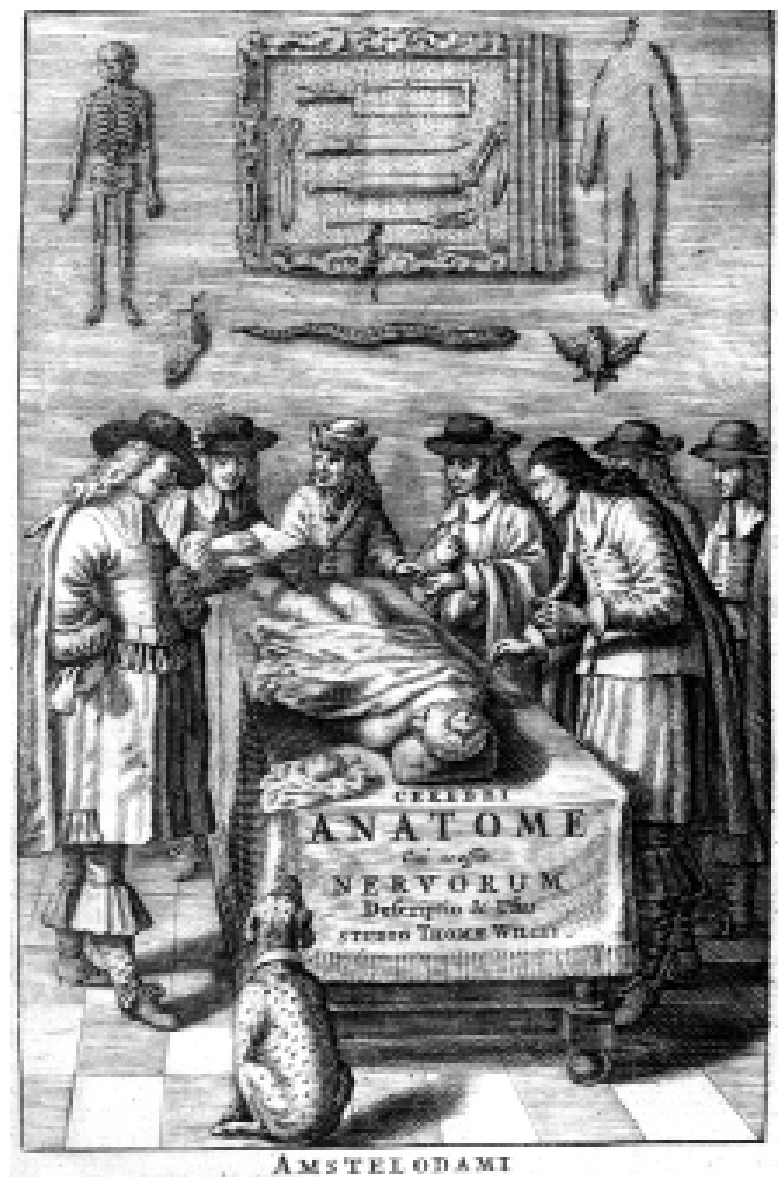

Apud GensRandur Schacex. M. DC.IXV.

FIG. 25. The frontispiece to Thomas Willis' Cerebri Anatome (Amsterdam: Gerbrandt Schagen, 1666). Thomas Willis introduced a new numbering system of the cranial nerves, grouped according to function; extensive descriptions of the basal ganglia, brainstem, and cerebellum; detailed schemes of the vagal and sympathetic nerves supplying the viscera; and the classical description of the anastomotic arterial circle. ${ }^{28,55}$ This illustration appears only in the $1665 / 1666$ edition of Cerebri Anatome published in Amsterdam, not in the original 1664 edition published in London. The scene suggests Willis' circle of associates, including Willis to the left (all others looking toward him), Wren with sketchbook, and Lower pointing within the cranial dissection. ${ }^{21}$

$1569)$ in the 1530 s to prepare what might have been a text (De dissectione partium corporis humani libri tres) that could have eclipsed some of the impact of the Fabrica. Perhaps the most significant work of the period next to the Fabrica, it contained illustrations showing lifelike poses of bodies in nature, several uniquely demonstrating dissections of the brain. However, a feud between Estienne and Étienne over credit for the dissections postponed publication from 1539 until 1545. In addition, for unknown reasons that forever altered the work's artistic impact, and although the illustrations date to the 1530s, many of the woodcuts were altered before printing, resulting in crude reproductions of what were highly representative, skillful illustrations. In the forward to this work, Estienne complained of plagiarism, although he did not cite any particular work or author. There is evidence that

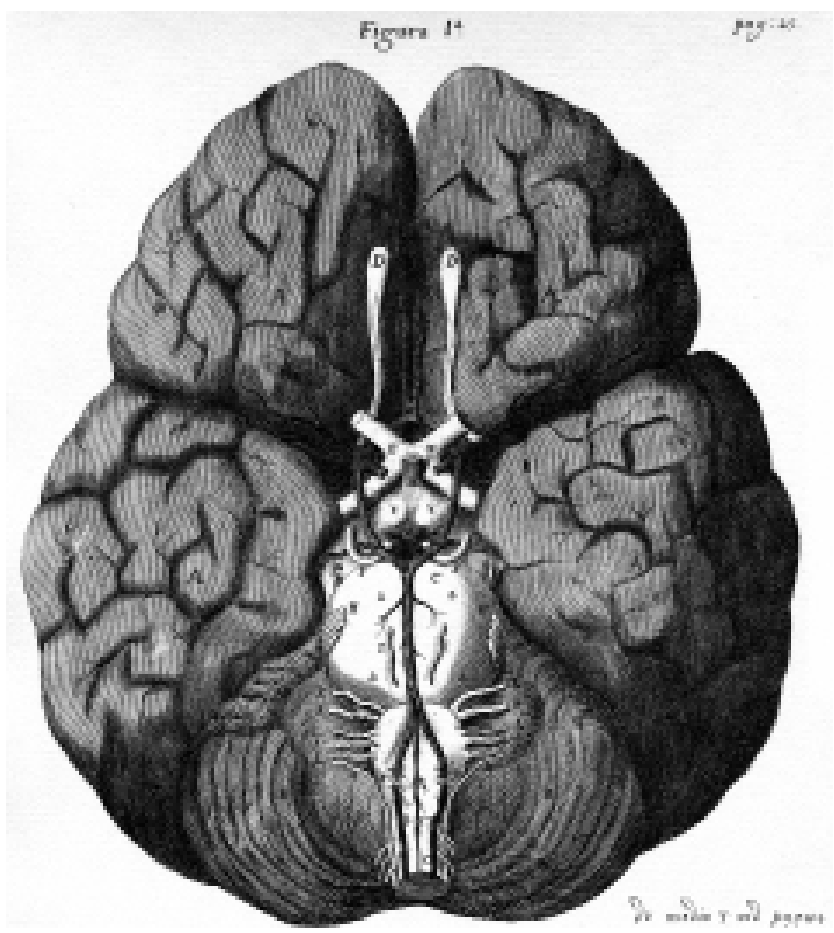

FIG. 26. Illustration of the base of a human brain revealing the circle of Willis, which is the first figure in Cerebri Anatome. Although the depicted cerebral convolutions were not of the highest quality, it can be argued that they serve as a background to the basal structures, which the author and artist wished to highlight. Some denominations still prevail, for example, cerebral peduncles and medullary pyramids. Although Nicolaus Steno (1638-1686) appropriately criticized the work of Willis, he stated that "the best figures of the brain up to the present are those presented to us by Willis."7,54

Vesalius had seen the work under preparation prepared in the mid-1530s when he was in Paris.

In 1664, Thomas Willis published his book on the anatomy of the brain and nerves, Cerebri Anatome (Fig. 25). ${ }^{54,55}$ Cerebri Anatome presented the first systematic approach to the functional anatomy of the brain. Willis ended the concept of ventricular localization of brain function and proposed 3 areas in the brain: the corpus striatum, corpus callosum, and cerebral cortex. He believed that these areas mediated the sensus communis, imagination, and memory, respectively. Willis' theory on brain function achieved widespread influence for more than a century until Albrecht von Haller (1708-1777) revised it. Charles Sherrington (1852-1952) remarked, "Thomas Willis practically refounded the anatomy and physiology of the brain and nerves...Willis put the brain and the nervous system on their modern footing so far as that could be then done." 39

The force of Willis' arguments was implemented by the excellence of the illustrations in Cerebri Anatome (Fig. 26). For Willis, these illustrations provided a vehicle to propose an end to the concept of localization of brain function-sensus communis, imagination, and memoryin the ventricles by transferring these to the 3 regions in the brain: corpus striatum, corpus callosum, and cerebral cortex, respectively. ${ }^{21,55}$ "Dr. Willis's Method of dissecting the Brain, (wherein he had the Assistance of the de- 


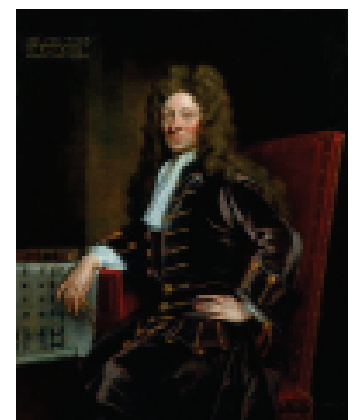

FIG. 27. Painting of Sir Christopher Wren, oil on canvas, by Sir Godfrey Kneller (1711). Wren was one of Willis' group of friends who experimented together in Beam Hall, Oxford, England, the first "neurological institute" 34 where Willis lived during his work on the Cerebri Anatome. ${ }^{22,55}$ Wren's drawings for Willis are also of interest as the only examples of any of Wren's drawings published before his death.

servedly famous Sir Christopher Wren, Dr. Millington, etc.) is new, and most natural, and so exact, that there is scarce anyone Part in it but what has receiv'd considerable advancements." 32

The impact of the illustrations in Cerebri Anatome reflected the artistic abilities of Christopher Wren (16321723; Fig. 27). One of Wren's main technical innovations was his development of a method to perform intravenous injection in animals. This made possible the injections of India ink and other substances into the carotid arteries, a technique used with great effect by Willis and Richard Lower (1631-1690) to define the collateral circulation to the brain and the physiological and pathological significance of the circle of Willis. In addition, Wren's injection method was undoubtedly applied to infuse alcoholic spirits into the autopsied brains. This gave Willis and his team the great advantage of attaining well-preserved specimens of brains that retained anatomical details for the artist.

Wren's familiarity with etching methods also gave him a technical edge in the production of his brain illustrations. ${ }^{55}$ Willis, referring to Wren as "Vir Insignissimus" ("most distinguished man"), wrote of his indebtedness to Wren in Cerebri Anatome: “...it becomes me not to hide, how much besides I did receive from...Dr. Chr. Wren...[who was] wont frequently to be present at our dissections, and to confer and reason about the uses of the parts...Dr. Wren, was pleased out of his singular humanity, wherewith he abounds, to delineate with his own most skilful hands, many figures of the brain and skull, whereby the work, might be more exact" 55 (Fig. 28).

Although not all the illustrations in Cerebri Anatome were drawn by Wren, his illustrations hold center stage and are easily identified from the others by their line, perspective, and objectivity. For Willis to have an expert in architecture and anatomy render images of the brain was ingenious, and the time was especially fortuitous. After the summer of 1663, architecture became Wren's main concern and with this last excellent effort, he abandoned his formerly lively interest in physiological and anatomical problems.

\section{Brain Illustrations Contemporary to Willis and Wren in the Works of Descartes}

Although the legacy of Willis and Wren was critical for brain illustration, a few of the illustrations within the contemporary works of René Descartes (1596-1650) are also notable for their realism and objectivity. In his 1662 De homine, and in its French translation 2 years later (L'homme), several of the illustrations of the brain are exquisitely rendered and more realistic than those in Willis' works, despite being within a work by an author who had no interest in the surface of the brain (Fig. 29) ${ }^{17,18}$ These illustrations have become largely ignored as Descartes was concerned with a mechanistic view of body function. Most of his illustrations were diagrammatic in nature, while the few excellent realistic illustrations bear little
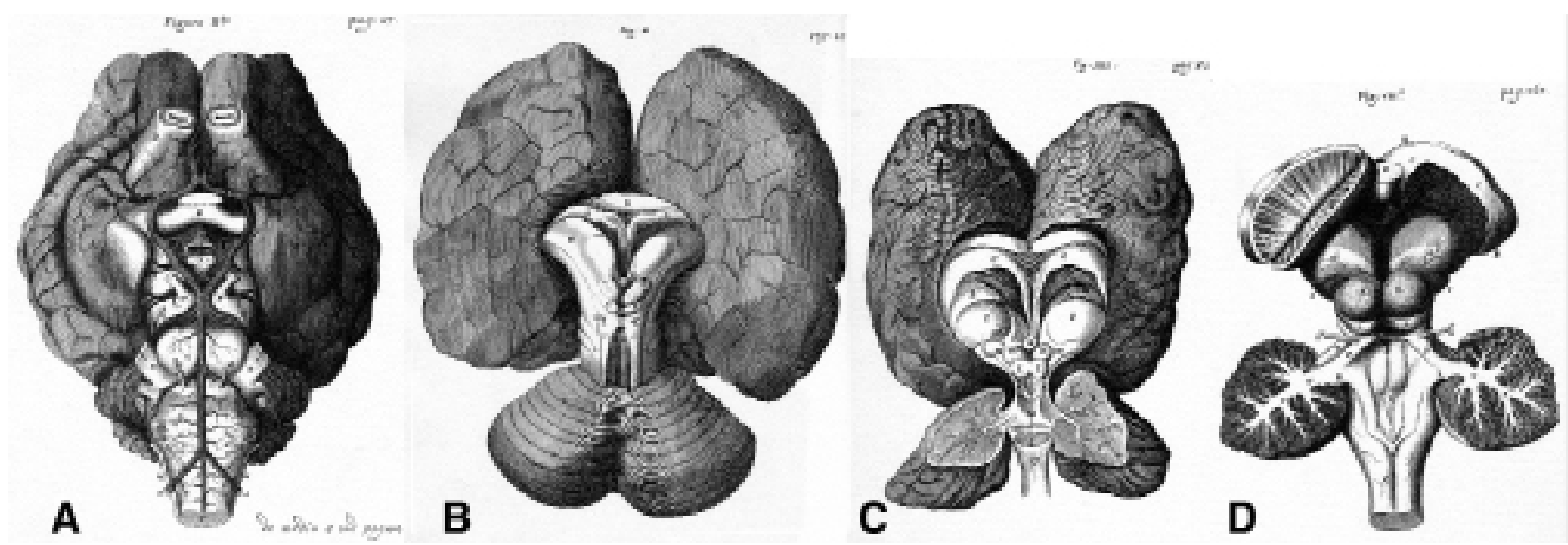

FIG. 28. Illustrations from the Cerebri Anatome. The superb drawings displayed the crisp elegance of Wren's expert draftsmanship and depicted the brain and nerves more accurately than anything previously published. Wren was intimately familiar with anatomy, as he had performed numerous physiological and anatomical experiments, including building models of muscles and the eyes, and had developed a means to perform intravenous injections in animals. ${ }^{54} \mathrm{~A}$ : The second figure in the book, the inferior surface of a sheep brain revealing the circle of Willis. B: The third figure of the book, depicting an unusual superior view of the dissected human brain. C: The fourth figure depicts the brain of a person presenting with congenital idiocy. D: The eighth figure, in which the cerebellum had been sagittally split to provide a dorsal view of a sheep brainstem. 


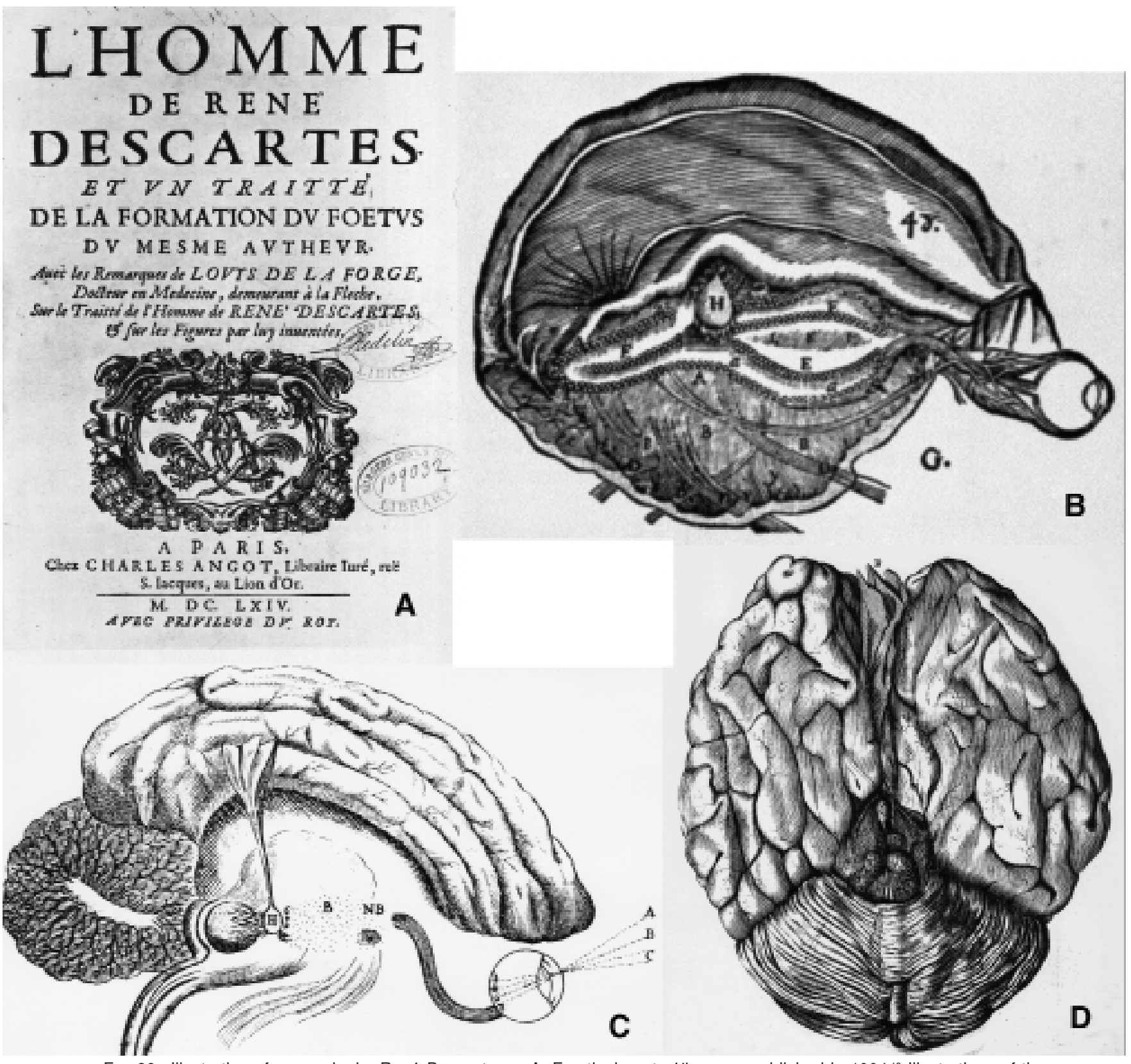

FIG. 29. Illustrations from works by René Descartes. A: Frontispiece to L'homme, published in $1664 .{ }^{18}$ Illustrations of the brain were inconsistently rendered in his books, probably because he had various artists executing the drawings, who were most likely untrained in rendering the brain. B: In addition, in L'homme, Descartes was more concerned with physiology. C and D: De homine had revealed more emphasis on neuroanatomy. .7,18 $^{18}$

relationship to the aims of his works. Illustrations of the brain were inconsistently rendered in Descartes' books, probably because he had various artists, most likely untrained in rendering the brain, executing the drawings. Unfortunately the artist of De homine remains unknown.

\section{Imaging the Brain During the Enlightenment}

After Willis and Wren, the combination of brain anatomy and progressive brain illustration stagnated until the late 18th century. Beginning at this time, however, abstract symmetries and proportions received renewed emphasis due to profound changes occurring in the study of natural history. Félix Vicq d'Azyr (1748-1794), applying contemporary French crystallographic research principles toward the study of the brain,,$^{42}$ advocated for calibrated, sequential stripping away of tissue structure and was at the vanguard of nomenclature standardization. ${ }^{51}$ To this end, he experimented with various preservative solutions to achieve optimal fixation and preservation of the brain, which allowed for highly complex and systematic drawings of the brain, especially subcortical structures.

\section{Precise and Technical Brain Illustrations}

Pierre (or Petrus) Camper (1722-1789) and Samuel 


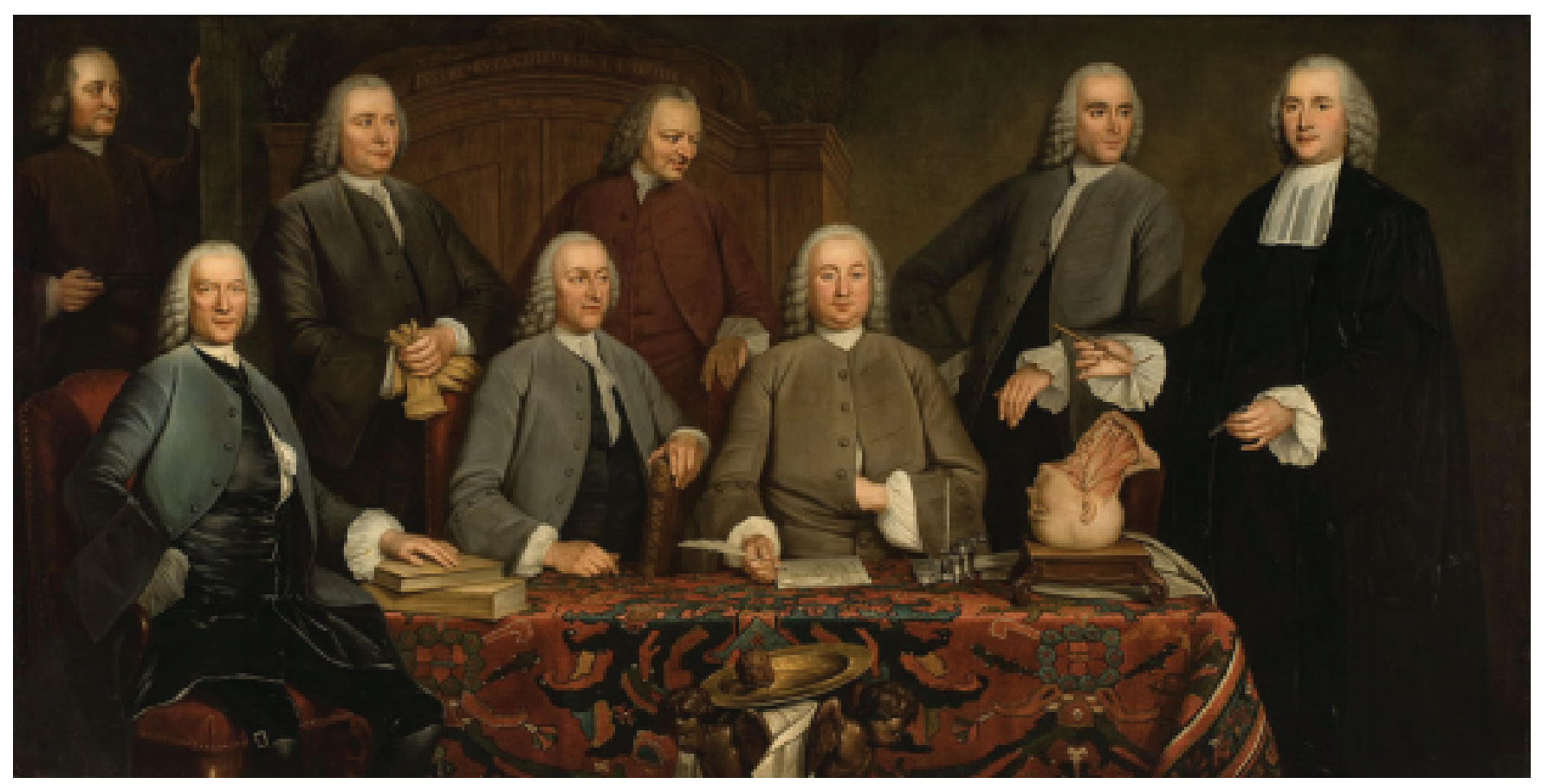

FIG. 30. The Anatomy Lesson by Dr. Petrus Camper, oil on canvas, by Tibout Regters (1758). During the Enlightenment, Petrus Camper introduced means of applying precision, including in illustration, to the study of comparative anatomy. Instead of drawing skulls freehand, Camper drew them according to measurements obtained from 3 polarized points.

Thomas Soemmerring (1755-1830) importantly introduced a means of applying precision, including in illustration, to the study of comparative anatomy, concentrating on the head and brain. This work was aligned with the work of Vicq d'Azyr and consistent with an interest during the Enlightenment of dividing the world or the body into accessible parts and investigating what lay beneath the exterior. Pierre Camper, a surgeon, was skilled in anatomical drawing and perspective (Fig. 30). One of his main accomplishments was developing a "body calculus" ${ }^{\prime 2}$ that he promoted in an anatomy book intended for art students. He provided illustrations of the head that portrayed precisely measured skulls with a system of straight lines and angles superimposed. These standardized line engravings possessed a technical appearance and were executed according to a geometrical method in which the subject was viewed from a wandering visual point. Soemmerring (Fig. 31) was so intent on following and rendering nature and its hidden aspects as closely as possible that he trained the gifted artist, Christian Koeck, to render his studies of brain anatomy and carefully supervised the engraver, Ludwig Schmidt, for his work Über der Organ der Seele, published in 1796. ${ }^{7,41}$

\section{Brain Illustration at the Close of the 18th Century}

The close of the 18th century witnessed the beginnings of a science that melded form and function (cerebral localization), as represented in the work of Franz Joseph Gall (1758-1828) and Johann Caspar Spurzheim (17761832). Perhaps the epitome of brain illustration during the Enlightenment is the work of Charles Bell (1774-1842), who was both a surgeon and a gifted artist (Fig. 32). Bell summed up the challenge of producing realistic brain images in the "Advertisement" section of his work (Fig. 33):

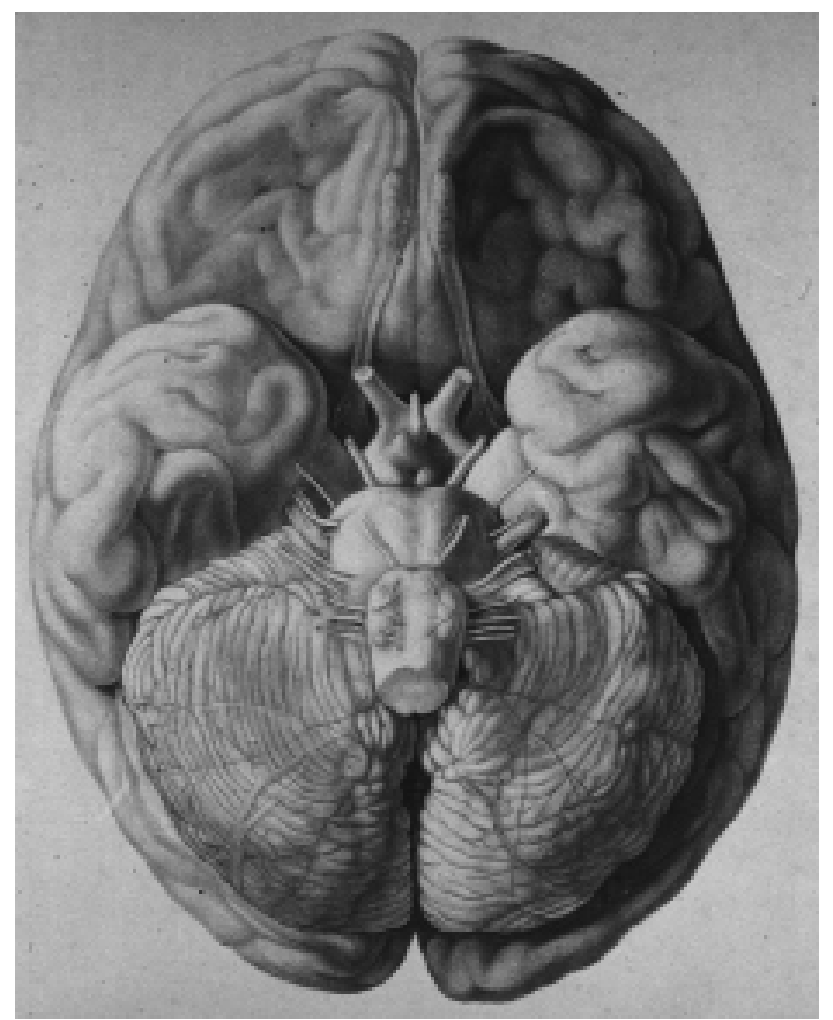

FIG. 31. Illustration depicting the base of a human brain from Über der Organ der Seele (1799), by Samuel Thomas Soemmerring, who was noted for the clarity and accuracy of his brain illustrations. ${ }^{41}$ 


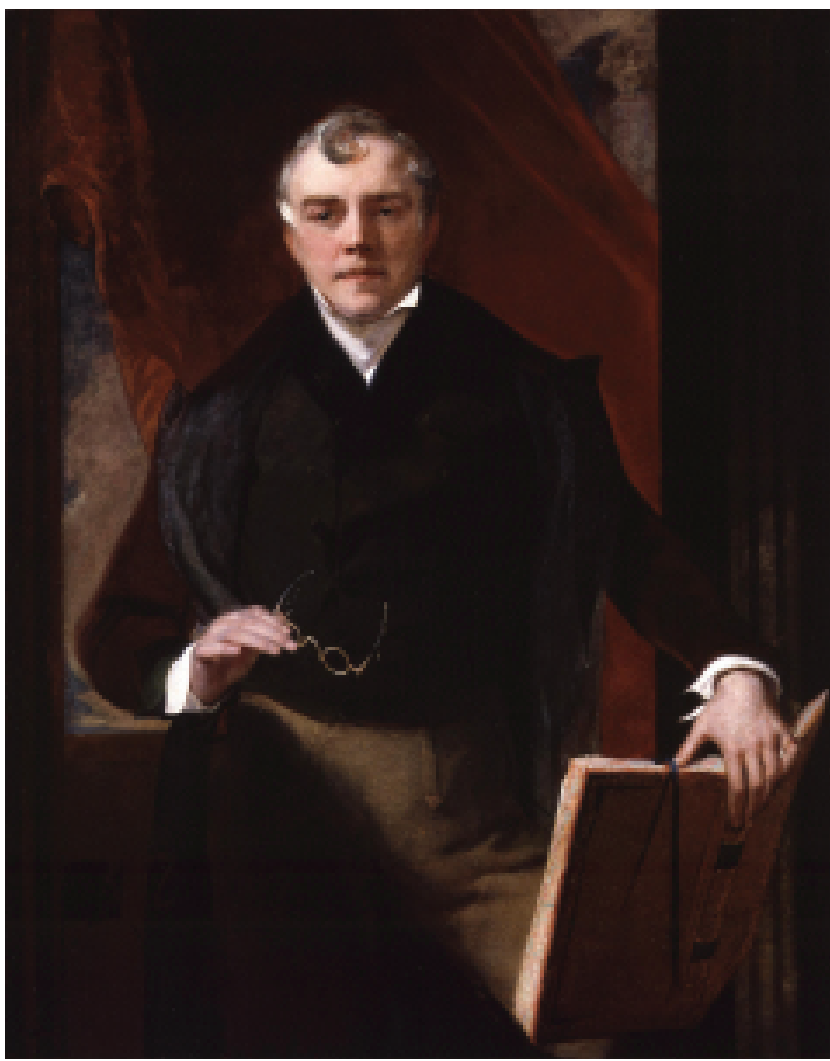
(1821).

FIG. 32. Portrait of Sir Charles Bell, oil on canvas, by John Stevens

In proportion to the delicacy of the Brain is the difficulty of investigating its parts and structure; but to represent those evanescent forms and parts by drawing, is altogether impracticable by a common artist unacquainted with Anatomy. If the most celebrated Anatomists, even when employed in representing the coarser parts, as Bones and Muscles, have been solicitous to retain, during all their lives, the same artists in their service, that they might profit by that superficial accuracy and slight degree of professional knowledge which men so educated could acquire, what should be necessary to an artist who proposes to represent the Anatomy of the Brain? He must be possessed, not merely of such superficial knowledge as may enable him to distinguish, by their characteristics, the Muscles and Tendons, the Arteries and Veins; but he must also be well acquainted with the various drawings and descriptions of authors, and understand the meaning of their terms; for although his business, no doubt, is to copy accurately from the dissected Brain, yet such previous knowledge, and study of the subject, give to his representations a minuteness of intention which cannot otherways be attained. ${ }^{4}$

\section{Conclusions}

Portraying the brain in a natural, objective, realistic manner developed in an era when anatomy, optical science, and visual art became interconnected. Beginning with Leonardo, art produced on a scientific basis no longer differed from science; the art of science and the science of art became aligned. In a very real sense the transition toward a new perspective of brain illustration was part of a notion of invention, search, and portrayal of the truth by a mathematical, or at least a systematic,

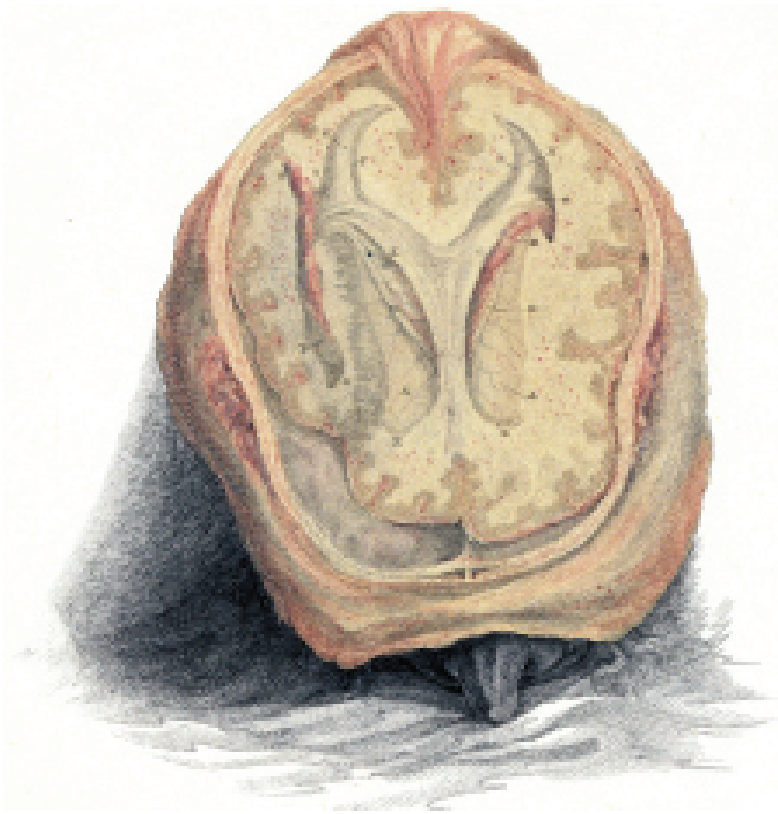

FIG. 33. Illustration of an axial section through the head demonstrating the anatomy of the lateral ventricles and fornix, from The Anatomy of the Brain, Explained in a Series of Engravings, by surgeon and artist Charles Bell. Bell accurately and stylishly sketched various views of brain dissections he had made. To print them, Bell worked closely with talented artists, including T. Medland, John Stewart, Freeman (first name unknown), and William Archibald, who produced the remarkable engravings. Stewart produced this engraving. ${ }^{4}$

model upon which the Renaissance and Enlightenment were founded.

Art and science advanced with respect to anatomical illustration within the context of specific social structures, in this case a "culture of dissection" (Fig. 34). Perhaps the historical coincidence of relaxing proscriptions surrounding the use of the dead for scientific investigation, concomitant with other revolutions in thinking during the Renaissance, catalyzed the systematic investigation and illustration of the relationship of the mind to the body.

Imaginative, inspirational, and aesthetic motives underlie the works of Leonardo, Vesalius and the Titian school, Willis and Wren, and others mentioned. These men stood at the vanguard of the common ground between the visions of the scientist and the artist. Overall, however, the artist was ahead of science. Accurate brain drawings were not accompanied by equivalent accurate knowledge of brain function, pathways, or connections. Perhaps not until Fritz and Hitzig mapped the precentral gyrus did the technology catch up to the art, and by then an urge to illuminate and define the ultrastructure of the brain was beginning.

At the end of the 15th century, Leonardo perceptively recognized the revolutionary philosophy of combining art with the natural world, as in anatomy, and indeed the drawings he rendered have no adequate words to describe them:

With what words $\mathrm{O}$ writer can you with a like perfection describe the whole arrangement of that of which the design is here? 


\section{The history of perspective in brain illustration}
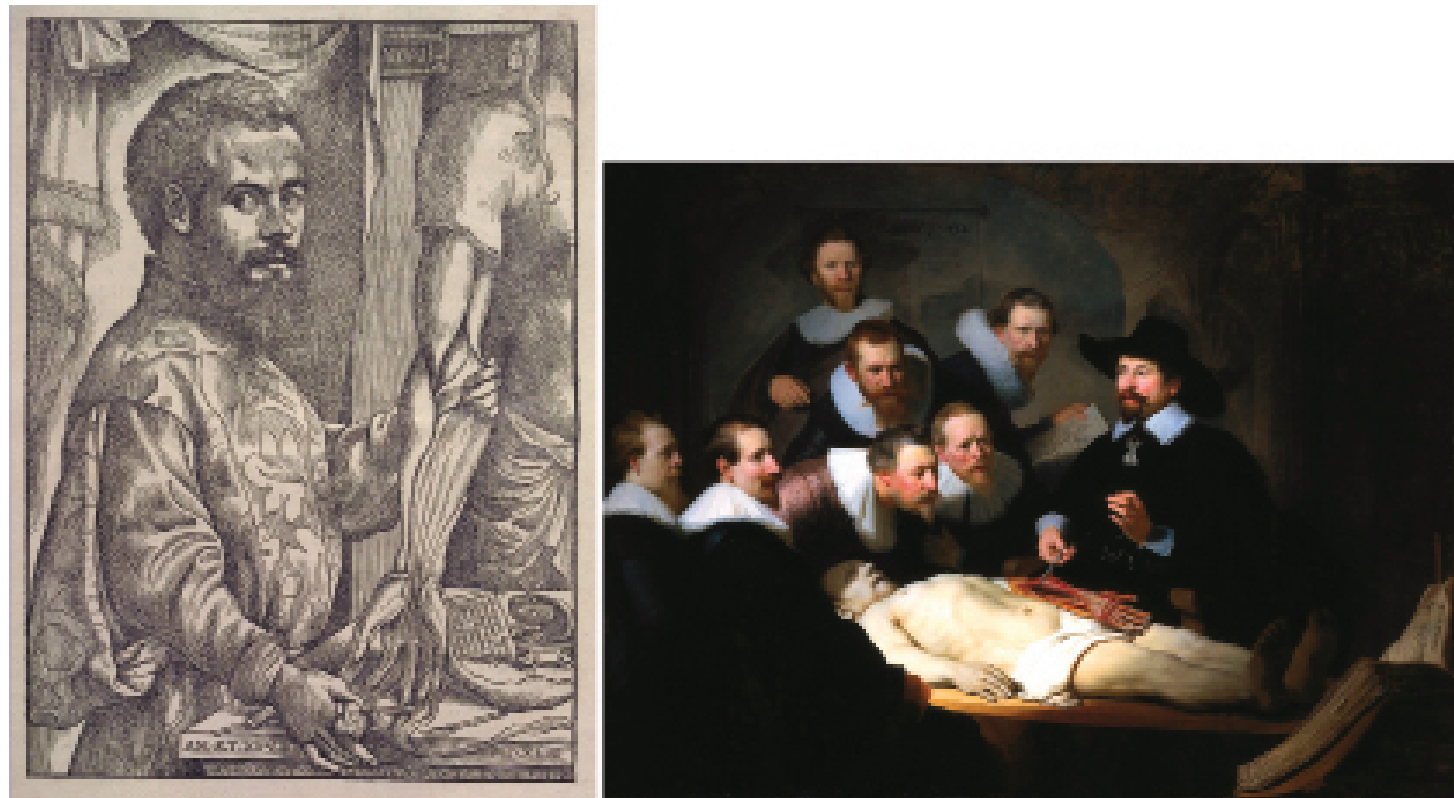

FIG. 34. Images representing the perfect nexus of art and science. The curious, intimate, and fortuitous connection between art and science and its progression through time may have been best illustrated in the final days of Rembrandt van Rijn (1606-1669). Two days before Rembrandt's death, a genealogist and antiquarian who visited him recorded that Rembrandt, having gone through a severe bankruptcy settlement in 1656, still had some rather intriguing possessions. While his contemporary Rubens had amassed wealth and a library, Rembrandt cherished peculiar, odd items that he believed retained some good use or were of sentimental value. Among his remaining items the antiquarian accounted "four flayed arms and legs anatomized by Vesalius." ${ }^{37}$ One of these pickled arms, floating perfectly preserved in a large glass jar, had not only been used as the model for the forearm in Rembrandt's 1632 masterpiece The Anatomy Lesson of Dr. Nicolaes Tulp, but had also served, nearly a century earlier, as the anatomical subject shown dissected by Vesalius in the woodcut portrait in the 1543 Fabrica. ${ }^{37}$ Left: Woodcut portrait of Vesalius in the Fabrica depicts what is reputed to be the most accurate representation of Vesalius' physical appearance. $^{46}$ Right: The Anatomy Lesson of Dr. Nicolaes Tulp, oil on canvas, by Rembrandt van Rijn (1632).

For lack of due knowledge you describe it so confusedly as to convey but little perception of the true shapes of things, and deceiving yourself as to these you persuade yourself that you can completely satisfy the hearer when you speak of the representation of anything that possesses substance and is surrounded by surface.

I counsel you not to cumber yourself with words unless you are speaking to the blind. If however notwithstanding you wish to demonstrate in words to the ears rather than to the eyes of men, let your speech be of things of substance or natural things, and do not busy yourself in making enter by the ears things which have to do with the eyes, for in this you will be far surpassed by the work of the painter.

How in words can you describe this heart without filling a whole book? Yet the more detail you write concerning it the more you will confuse the mind of the hearer. And you will always then need commentators or to go back to experience; and this with you is very brief, and has to do only with a few things as compared with the extent of the subject concerning which you desire complete knowledge. ${ }^{27}$

LEONARDO DA VINCI (CIRCA 1487)

\section{Disclaimer}

The authors report no conflict of interest concerning the materials or methods used in this study or the findings specified in this paper. All images used in this paper are in the public domain.

\section{References}

1. Alberti LB: On Painting and On Sculpture. The Latin Texts of De pictura and De statua. London: Phaidon, 1972

2. Arderne J, Power D, Millar E: De Arte Phisicali et de Cirurgia of Master John Arderne, Surgeon of Newark, Dated 1412. New York: Willian Wood and Co., 1922

3. Ariès P: The Hour of Our Death. New York: Knopf, 1981

4. Bell C: The Anatomy of the Brain: Explained in a Series of Engravings. London: Longman and Rees, 1802

5. Calkins CM, Franciosi JP, Kolesari GL: Human anatomical science and illustration: the origin of two inseparable disciplines. Clin Anat 12:120-129, 1999

6. Casserius J: Tabulae Anatomicae. In Operaquae Extant, Platex. Amsterdam: Spigelius, 1645

7. Clarke E, Dewhurst K: An Illustrated History of Brain Function: Imaging the Brain From Antiquity to the Present. San Francisco: Norman Publishing, 1996

8. Clarke E, O'Malley CD: The Human Brain and Spinal Cord: A Historical Study Illustrated by Writings From Antiquity to the Twentieth Century, ed 2. San Francisco: Norman Publishing, 1996

9. Clayton M, da Vinci L, Philo R: Leonardo da Vinci: The Anatomy of Man: Drawings from the Collection of Her Majesty Queen Elizabeth II. Boston: Bulfinch Press, 1992

10. Cohn AE: Medicine, Science and Art: Studies in Interrelations. Chicago: The University of Chicago Press, 1934

11. Cromwell PR: Decline and Rebirth of Polyhedral Geometry, in Polyhedra. Cambridge: Cambridge University Press, 1999, pp 115-116 
12. Cushing H, Fulton JF: A Bio-Bibliography of Andreas Vesalius. New York: Schuman's, 1943

13. da Vinci L, Vangensten OCL, Fonahn A, Hopstock H: Quaderni d'anatomia. Christiania: Jacob Dubwad, 1911-1916

14. de Santillana G: The role of art in the scientific renaissance, in Clagett M (ed): Critical Problems in the History of Science. Madison, WI: University of Wisconsin Press, 1959, pp 3-23

15. dei Liucci M: Anatomia. Bologna: L. Cappelli, 1930

16. della Francesca P: De Prospectiva Pingendi, in Nicco-Fasola G (ed): Casa Editrice le Lettere. Florence: Sansoni, 1984

17. Descartes R: De Homine Figuris et Latinitate Donatus a Florentino Schuyl. Leiden: Moyardum and Leffen, 1662

18. Descartes R: Traite de l'homme. Paris: Charles Angot, 1664

19. Di Ieva A, Tschabitscher M, Prada F, Gaetani P, Aimar E, Pisano P, et al: The neuroanatomical plates of Guido da Vigevano. Neurosurg Focus 23(1):E15, 2007

20. Dryander J: Anatomiae, Hoc Est, Corporis Humani Dissectionis Pars Prior. Marburg: Apud Eucharium Ceruicornum, 1537

21. Feindel W: The beginnings of neurology: Thomas Willis and his circle of friends, in Rose FC (ed): A Short History of Neurology: The British Contribution, 1660-1910. Oxford: Butterworth-Heinemann, 1999, pp 1-18

22. Feindel W: Domus Willisi: a neuro-architectural tour. J Hist Neurosci 5:87-99, 1996

23. Goodrich JT: A millennium review of skull base surgery. Childs Nerv Syst 16:669-685, 2000

24. Goodrich JT: Sixteenth-century Renaissance art and anatomy: Andreas Vesalius and his great book-a new view. Med Herit 1:280-288, 1985

25. Hanigan WC, Ragen W, Foster R: Dryander of Marburg and the first textbook of neuroanatomy. Neurosurgery 26:489498, 1990

26. Kemp M: The Science of Art: Optical Themes in Western Art From Brunelleschi to Seurat. New Haven: Yale University Press, 1992

27. MacCurdy E: The Notebooks of Leonardo da Vinci. New York: George Braziller, 1956

28. Molnar Z: Thomas Willis (1621-1675), the founder of clinical neuroscience. Nat Rev Neurosci 5:329-335, 2004

29. O'Malley CD: Andreas Vesalius of Brussels, 1514-1564. Berkeley: University of California Press, 1964

30. O'Malley CD, Saunders JB De CM: Leonardo da Vinci on the Human Body: The Anatomical, Physiological, and Embryological Drawings of Leonardo da Vinci: With Translations, Emendations and a Biographical Introduction. New York: Henry Schuman, 1952

31. Peccatori S, Zuffi S (eds): Piero della Francesca. London: Dorling Kindersley, 1999

32. Plot R: The Natural History of Oxfordshire. Oxford: Printed at the Theater, 1677

33. Pons A, d'Alembert JLR: Encyclopédie ou Dictionnaire Raisonné des Sciences, des Arts et des Métiers: Articles Choisis. Paris: Flammarion, 1986

34. Preul MC, Feindel W: Domus Willisi and the first neurological institute. J Neurosurg 94:399A-400A, 2001 (Abstract)

35. Saunders JB de CM: O'Malley CD: The Illustrations From the Works of Andreas Vesalius of Brussels. A Discussion of the Plates and a Biographical Sketch of Vesalius: With Annotations and Translations. New York: Courier Dover Publications, 1973

36. Sawday J: The Body Emblazoned: Dissection and the Human Body in Renaissance Culture. London: Routledge, 1996

37. Schama S: Rembrandt's Eyes. Toronto: Random House of Canada 1999

38. Schumacher GH: Theatrum anatomicum in history and today. Int J Morphol 25:15-32, 2007
39. Sherrington CS: Man on His Nature. Cambridge: University Press, 1941

40. Singer CJ: Vesalius on the Human Brain. London: Oxford University Press, 1952

41. Sömmerring ST: Über das Organ der Seele. Köningsberg: Nicolovius, 1796

42. Stafford BM: Body Criticism: Imaging the Unseen in Enlightenment Art and Medicine. Cambridge: MIT Press, 1993

43. Sudhoff K: Ein provenzalischer anatomischer Traktat aus dem 13. Jahrhundert, in Ein Betrag zur Geschichte der Anatomie im Mittelalter speziell der anatomischen Graphik nach Handschriften des 9. bis 15. Jahrhunderts. Studien zur Geschichte der Medizin. Leipzig: J.A. Barth, 1908; facsimile reprint Hildesheim: Georg Olms, 1964

44. Vasari G: The Lives of the Painters, Sculptors and Architects. London: Dent, Vol 1, 1963

45. Vasari G, Bull G: The Lives of the Artists. New York: Penguin Books, Vol 2, 1987

46. Vesalius A: De humani corporis fabrica Libri septem. Basileae: Ex Officina Joannis Oporini, Mense Junio, 1543

47. Vesalius A: Tabulae Anatomicae Sex. Venice: Bernardus, 1538

48. Vesalius A, Dubois J, Oporinus J: Epistola, rationem modumque propinandi radicis Chynae decocti . . . pertractans: \& praeter alia quaedam, epistolae cujusdam ad Jacobum Sylvium sententiam recensens, veritatis ac potissimum humanae fabricae studiosis perutilem: quum quî hactenus in illa nimium Galeno creditum sit, facile commonstret. Basel: Ex officina Joannis Oporini, 1546, p 194

49. Vesalius A, Lind LR: The Epitome of Andreas Vesalius. New York: Macmillan, 1949

50. Veslingius J: Syntagma Anatomicum. Padua: Frambotti, 1651

51. Vicq-d'Azyr F, Cloquet JH: Encyclopédie Méthodique ou par Ordre de Matières: Systême Anatomique. Dictionnaire Raisonne des Termes d'Anatomie et de Physiologie. Paris: Chez Mme. Veuve Agasse, Vol 1, 1823

52. von Schlosser J (ed): Lorenzo Ghiberti's Denkwurdigkeiten (I commentarii) zum ersten male nach der handschrift der Biblioteca nazionale in Florenz vollständig. Berlin: J. Bard, 1912

53. Watkins R: Newes From the Dead or a True and Exact Narration of the Miraculous Deliverance of Anne Greene. Oxford: Robinson, 1651

54. Willis T: Cerebri anatome: cui accessit nervorum descriptio et usus. Londini: Typis Ja. Flesher, impensis Jo. Martyn \& Ja. Allestry, 1664

55. Willis T, Feindel W, Pordage S: The Anatomy of the Brain and Nerves. Montreal: McGill University Press, 1966

Manuscript submitted May 19, 2009.

Accepted July 21, 2009.

This paper was presented, in part, at the 2000 Annual Meeting of the American Association of Neurological Surgeons, San Francisco, California, on April 24, 2001, and at the 2009 Annual Meeting of the American Association of Neurological Surgeons, San Diego, California, on May 5, 2009.

Address correspondence to: Mark C. Preul, M.D., c/o Neuroscience Publications, Barrow Neurological Institute, 350 West Thomas Road, Phoenix, Arizona 85013. email: mark.preul@chw. edu. 